University of San Diego

Digital USD

1993

\title{
A Framework of Transformational Leadership Concepts Proposed for Undergraduate College and University Student Development and Student Affairs Leadership Programs
}

Stanley D. Fasci EdD

University of San Diego

Follow this and additional works at: https://digital.sandiego.edu/dissertations

Part of the Leadership Studies Commons

\section{Digital USD Citation}

Fasci, Stanley D. EdD, "A Framework of Transformational Leadership Concepts Proposed for Undergraduate College and University Student Development and Student Affairs Leadership Programs" (1993). Dissertations. 580.

https://digital.sandiego.edu/dissertations/580

This Dissertation: Open Access is brought to you for free and open access by the Theses and Dissertations at Digital USD. It has been accepted for inclusion in Dissertations by an authorized administrator of Digital USD. For more information, please contact digital@sandiego.edu. 


\section{A FRAMEWORK OF TRANSFORMATIONAL LEADERSHIP CONCEPTS PROPOSED FOR UNDERGRADUATE COLLEGE AND UNIVERSITY STUDENT DEVELOPMENT AND STUDENT AFFAIRS LEADERSHIP PROGRAMS}

by

Stanley D. Fasci

A dissertation submitted in partial fulfiliment

of the requirements for the degree of

Doctor of Education

University of San Diego

1993

Dissertation Committee

Susan M. Zgliczynski, Ph.D., Director William P. Foster, Ed.D. Edward Kujawa, Jr. Ph.D. 


\section{ABSTRACT}

A Framework of Transformational Leadership Concepts Proposed for Undergraduate College and University student Development and student Affairs Leadership Programs.

FASCI, STANLEY D., Ed.D.

University of San Diego, 1993. 129 pp.

Director: Susan M. Zgliczynski, Ph.D.

Educating undergraduate students in the area of

leadership has long been part of the educational mission of many public and private institutions of higher education in the United States. At many of these colleges and universities, leadership education and training has been accomplished by programs directed by student development or student affairs divisions of the institution. The purpose of this study was to identify a framework of transformational leadership concepts that could be integrated into existing student development/affairs leadership programs. The study's objectives were: (1) to obtain expert opinion regarding transformational leadership concepts to be used; (2) to verify whether or not the concepts are found in the current literature and presently included in a select number of leadership programs; and (3) to provide a framework for integrating the concepts into existing programs.

The methodology used combined the qualitative research techniques of the Delphi Technique and the Focus Group Interview. A panel of seven professionals, identified as 
experts in the area of transformational leadership, completed two rounds of questionnaires. The questionnaires collected nominations from panelists on: (1) what concepts would be necessary to introduce the topic of transformational leadership to undergraduates in a leadership program; (2) what sequence these concepts should be presented in; and (3) how these transformational leadership concepts could be best communicated to undergraduate students.

Some of the findings of the study were: (1) Empowerment, Sharea Power/Shared Leadership, Vision and Values/Ethics were nominated as the transformational leadership concepts to be included in the framework. These concepts were found in the literature, but as a rule were not included in a select number of current programs. (3) One example of a typical suggestion made by several panelists was that leadership training should be integrated with each student's personal experience.

Finally, based on his expert opinion, the researcher suggested additional transformational leadership concepts and strategies for integrating concepts into student development/affairs leadership programs. 


\section{COPYRIGHT 1993}

Reproduced with permission of the copyright owner. Further reproduction prohibited without permission. 


\title{
DEDI CATION
}

\author{
To Rev. Harry E. Hoewischer, S.J., \\ whose counsel, guidance and friendship \\ fostered transformational change in my life.
}




\section{ACKROWLEDGEMENTS}

To my late father Dominick, my mother Gladys and my sisters Angela and Maria. Thank you for all your unfailing love and support throughout my $l$ ife and all the ways that you have shown that.

To Mark Gleba and Mark Landerghini, my two dearest friends. Your love and friendship has made all the difference in my life.

To Tere Feterson, who has been with me as a fellow student throughout these doctoral studies. The generosity of your love, support and friendship has made this experience a delightful and memorable one.

To Dr. Jonathan Kramer, your wisdom, caring counsel and friendship have been an invaluable contribution to my life these past three years.

To Patricia and Tom Gleba, thank you for your love and support shown in so many ways. A special thanks to Pat for your editing and computer expertise that enriched and enhanced this study.

To Dr. Sue Zgliczynski, director of my disssztation, my advisor, professor, colleague and friend. You provided an environment for my creativity to develop and this dissertation study to emerge. Your mentorship and friendship has been invaluable to me over these past years in so many ways.

To Dr. Bill Foster and Dr. Ed Kujawa, my dissertation committee members. I am deeply grateful to each of you for your help and guidance in the completion of this dissertation study. Your contributions as scholars in the doctoral program are immensely appreciated.

To Dr. Joseph Rost and Dr. Mary Scherr, I sincerely appreciate your dedication to the doctoral program. Your teaching and scholarship enriched my educational experience in many ways.

To the panelists who participated in this study. I am deeply grateful for your expertise, time and energy expended for this research project.

And finally, to the Jesuits of the Missouri Province of the society of Jesus, for their unconditional support. 
DEDICATION..........................

ACKNOWLEDGEMENTS $\ldots \ldots \ldots \ldots \ldots \ldots \ldots \ldots \ldots \ldots \ldots \ldots \ldots \ldots \ldots$

TABLE OF CONTENTS.......................

LIST OF FIGURES.........................

LIST OF TABLES......................... viii

APPENDICES ..........................

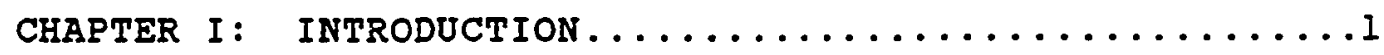

The Background of Leadership Education

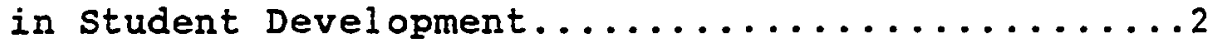

Statement of the Issue...................

Purpose of the study....................

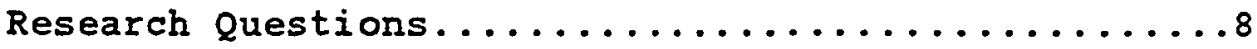

The Significance of this study for college and

University Leadership Programs............

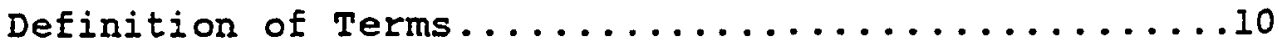

Assumptions and imitations of this study..........II

CHAPTER II: REVIEW OF THE LITERATURE............

A History of the Current Status of student

Development Leadership Programs............14

Programming and Training in student Development.....18

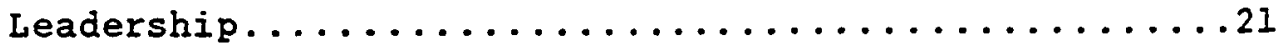

Transformational Leadership.................... 4

Moral, Ethical, or Value orientated........26

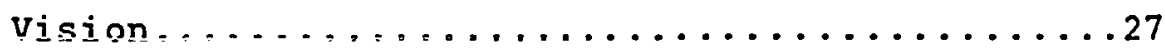

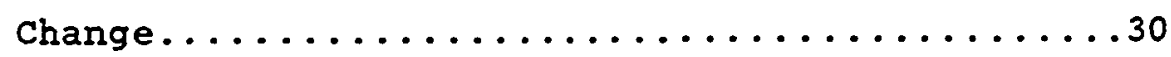

Empowerment and Shared Leadership...........31

Social Responsibility and Democracy..........33 
Summary of the Literature Review..................

CHAPTER III: INTRODUCTION.....................

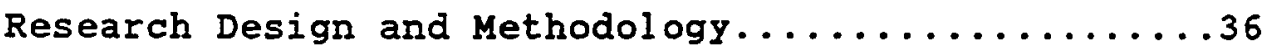

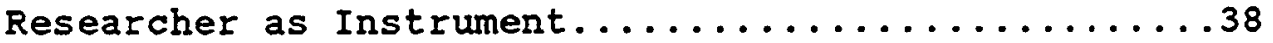

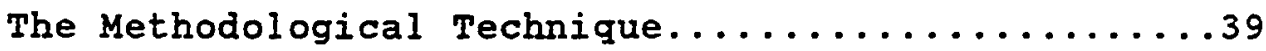

Expert Panel Selection..................4l

Panel size..........................43

Developing the Initial questionnaire...........44

Developing the Follow-Up Questionnaire..........44

Methodology and Documentation Process Flow.......48

Data Analysis and Implications..............50

Potential Concerns and Limitations

of the Research.......................53

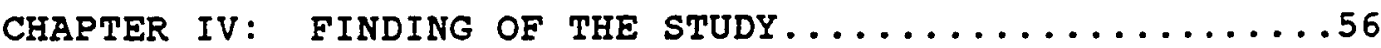

Panel Selection and Methodological Results.......57

Initial Questionnaire Results.............61

Follow-Up Questionnaire Results.............64

Part I: Questionnaire Results...........64

Part II: Questionnaire Results..........67

Selecting the Concepts................

Concepts Examined with student

Development Programs...................

Sequence in which Concepts should be Taught...75

Part III: Questionnaire Results..........76

Part IV: Questionnaire Results..........78

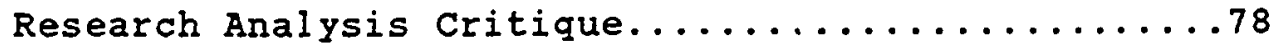

Sumnary of the Research Findings............8I 
CHAPTER V: SUMMARY AND RECOMMENDATIONS............83

Background Issues....................... 83

objectives of the study..................85

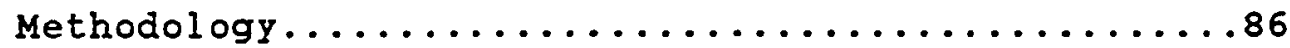

Research Findings....................

Findings of Research Questions I \& II......87

Findings of Research Question III.........90

Findings of Research Question IV..........92

Framework - Values/Ethics..........93

Framework - Vision...............95

Framework - Shared Power \&

Shared Leadership..............97

Framework - Empowerment............99

Researcher Recommendations...............101

Recommendations for Further Research.........103

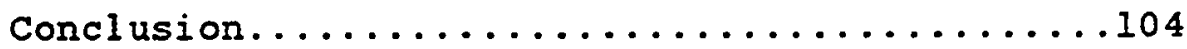

REFERENCES...............................

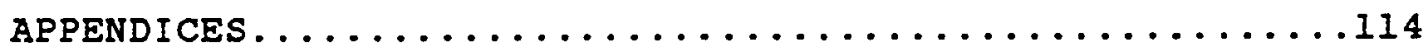




\section{LIST OF FIGURES}

Figure

Page

1. Follow-up Questionnaire Likert Scale Ranking......46

2. Methodology and Documentation Process Flow.......49

3. Expert Panel Member List of Names...............59

4. Selected Transformational Leadership Concepts......73

5. Framework of Transformational Leadership Concepts..93-100 
Table

Page

1. Recurrent Transformational Leadership Concepts....63

2. Panelists Responses to Concepts Being Included

in the Leadership Program..............66

3. Panelists Responses to Final Concept

Recommendations....................69

4. Final Panelists Recommendations to the Concepts

to be Included in the Leadership Program.......7I

5. Ranking of Five Panel ist Sequence in how

Concepts should be Introduced to students......76 


\title{
APPENDICES
}

\author{
Appendix A - Initial Introduction Letter \\ Appendix B - Background Information Questionnaire \\ Appendix C - Transformational Leadership Concept Sheet \\ Appendix D - USD Consent Form \\ Appendix E - Panelist Reject Letter \\ Appendix F - Panelist Selection Letter \\ Appendix G - Cover Letter for Follow-up Questionnaire \\ Appendix H - Part I, Panelists Evaluation of Concepts \\ Appendix I - Part II, Panelists Reevaluation of Concepts \\ Appendix J - Part III, Suggestions to Teach Concepts \\ Appendix K - Part IV, Reference Suggestions from Panelists \\ Appendix L - Student Development Course and Program List
}




\section{CHAPTER I}

\section{INTRODUCTION}

I was introduced to leadership education in the college and university setting when I accepted my first position in a student development office. One of my responsibilities was to help coordinate and administrate a new leadership program for undergraduate students at the university level. Both the administrative and academic areas of the university were supportive and involved with the leadership program. The university considered itself a pioneer in developing a program tailored to the specific needs and concerns of its students. But despite the enthusiasm and support for the program, the coordinating team soon found itself asking some tough questions regarding the nature of leadership and what the curriculum should include to teach leadership. That discussion precipitated my own interest of what leadership is and how it should be taught at the college and university level. The following study is the result of my research in student development leadership programs at the college and university level. 


\section{THE BACKGROUND OF LEADERSHIP EDOCATION IN STUDENT DEVELOPMENT}

The college and university student development profession, also referred to as student affairs, has changed considerably since the publication of The student Personnel Point of View in 1937. Historically the profession has moved from the in loco parentis focus of control, to service and support, to the current developmental perspective.

Leadership education in student affairs has emerged from this developmental movement. Undergraduate student leadership training programs became a focus of student development offices in both public and private colleges and universities in the United states. With an emphasis on the holistic development of the individual, and a desire for a more well-rounded student, leadership training developed as a major program goal for student development programs. At the same time, college educators were focused on a renewed interest in leadership development. Simultaneously the student development profession was redefining its role in relationship to leadership training.

As leadership programs emerged in the student development arena, they took on various forms and types. A variety of models were developed and integrated into a particular college or university setting. Specific programs varied in their objectives. They ranged from an experiential focus of practicing management techniques to an intellectual focus of understanding leadership qualities. 
Throughout the years student affairs professionals and their organizations made specific efforts to pool their resources and address the leadership education arena. Roberts' (1981) work a decade ago was one such resource and his word is still acclaimed as one of the most complete guidebooks for leadership programs (Gordon \& sindon, 1989). The Center for Creative Leadership provided another resource. The center annually publishes a source Book which contains course descriptions and syllabi on leadership programs throughout the country (See Clark \& Freeman, 1990). These works have provided some useful criteria for designing and implementing leadership programs, but the content of the material was not specific to leadership per se. Much of it could be just as easily applied to a variety of college student development programs.

The heart of the problem lies in the fact that the student affairs profession has never clearly identified the nature of leadership. When they have attempted to do so, they relied on outdated concepts. For instance, there is no effort to make a distinction between leadership and management.

Roberts' (1981) book still serves as a popular student development guide book for leadership programs. In his work, Roberts referred to leadership and management as being synonymous terms. Yet many authors have clearly called for a distinction between management and leadership (Bennis \& 
Nanus, 1985; Kouzes \& Posner, 1987; Palmer, 1989; Rost, 1991; Zaleznik, 1977, 1989).

Another problem with the student affairs literature is that leadership has been depicted as something that is done, or a trait that an individual possesses. Over forty years ago, Stogdill (1948) found that no consistent patterns existed when he reviewed over one-hundred trait studies. Calder (1977) noted that "more important, the trait approach did not distinguish between leadership as a process and the leader as a person" (p. 179).

Even when there was an attempt to update and expand leadership thinking, the results have been limited. A recent model program statement compiled by representatives from various student personnel professional associations stated, "leadership is demonstrated by those individuals designated as leaders and those who participate actively in the organization" (Brown, 1990, p. 227). Denhardt (1981) and Foster (1986) have noted that leadership is a pervasive phenomenon that comes and goes and is not linked to an office or position.

The examples listed here are not isolated ones but are endemic to the student affairs leadership literature. The pervasive thought about leadership development has been rooted in outdated and passe concepts of leadership. A focus that views leaders as office and position holders, leaves student development leadership programs emphasizing a managerial style of leadership training. 


\section{STATEMENT OF THE ISSOE}

student leadership education in higher education faces many new challenges as institutions embark upon the twentyfirst century. Single events, both globally and close to home, can result in dramatic changes that call for innovative leadership decisions. President clinton and his new administration confront tough issues in tackling problems with the economy, health care, and education. Our social climate as we know it today, faces an unknown future.

Educating college and university students with an understanding of leadership has never been an easy task. But educating students for leadership skills that may be needed in the future provides even greater challenges. No longer can traditional leadership skills provide the solutions that may confront tomorrow's leaders. The future may be a great deal different than we know it today. It is evident that current leadership practices require an understanding of issues that were not imagined in the past. Sensitivity to gender, diversity, and ethics are just a few of the issues that leaders must confront. The leaders of tomorrow must be skillful in leadership practices that embrace such issues.

The notion of transformational leadership incorporates numerous ideas that may provide the fabric needed for a renewal of leadership training. First introduced by James MacGregor Burns (1978) in his book on leadership, transformational leadership offers a vision that builds on 
Burns' idea of raising individuals to higher levels of motivation and morality.

The office of student development has had a long history of answering the call to educate leaders. Professionals in the student development arena have constructed a variety of programs to educate students in leadership. Numerous models have been developed to integrate leadership programs into a particular college or university setting. Yet a close examination of these programs reveals that most of them do not provide more than good management training.

Using the concepts of transformational leadership, this study endeavored to provide resources that would enhance leadership education needed for the future. The focus of the research done in this study was to identify transformation leadership concepts that could be integrated into student development leadership programs. This was accomplished by obtaining nominations from a panel of experts. These recommendations were cross checked with literature on transformational leadership and existing student development leadership programs. The results of this study provided concepts in transformational leadership that are, for the most part, missing in student development leadership programs. 


\section{PURPOSE OF THE STUDY}

The purpose of this study was to identify a set of transformational leadership concepts that provided a

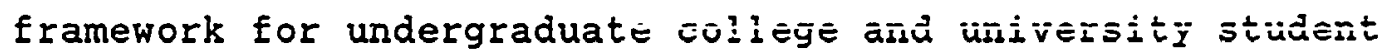
development leadership programs. The objective of the framework was that it be developed through the use of rigorous research methods. A systematic process that incorporated the qualitative research methods of the Delphi Technique (Linstone \& Turoff, 1975) and the Focus Group Interview (Patton, 1990) served to achieve this goal.

The research performed in the study identified a set of concepts that constructed the transformational leadership framework. The concepts that were presented in the framework were nominated by a panel of experts who had some knowledge base of transformational leadership. Panel members were taken through a feedback process which resulted in a set of identifiable concepts. This set of concepts was examined and validated by the current transformational leadership literature. These research methods provided an inquiry process which allowed the transformational leadership framework to emerge.

The purpose of the outlined set of concepts presented in this study supplements the material already available on leadership training and education in college and university student development leadership programs. The specified concepts presented in the framework serve as guide to enhance the knowledge provided by these programs. This 
study created a foundation which may enable others to investigate, develop and implement programs that use these suggested ideas, thus providing additional possibilities for

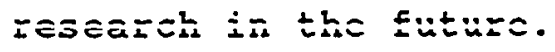

\section{RESEARCH QUESTIONS}

The following research questions were developed in order to satisfy the objectives and purposes of this study. 1. What concepts do experts say are necessary to introduce the topic of transformational leadership to undergraduate students in a student development leadership program?

2. Is each concept present in the current transformational leadership Iiterature?

3. Are these transformational leadership concepts included in the student development leadership course outlines or syllabi presented in the Leadership Education Source Book (Clark \& Freeman, 1990)?

4. What are the ways in which a transformational leadership concept can be integrated into a student development leadership program and what would the actual framework of concepts look like?

THE SIGNIFICANCE OF THIS STUDY FOR COLLEGE AND UNIVERSITY LEADERSHIP PROGRAMS.

The Leadershif Education Source Book (Clark \& Freeman, 1990) lists thirty-five leadership courses and thirty-three leadership programs on college and university campuses. of 
these sixty-eight courses and programs listed, nineteen are administered by or in connection with the student development office of a particular school. A review of the course outlines or syllabi of thise nineteen schools indicated that management skills and good management techniques were the training goals of the majority of programs.

There is a need for student development leadership programs to include transformational leadership theories that will assist students in the understanding of the leadership process. Leadership as a relationship occurs between leaders and followers. This study developed a blueprint using the foundational theories of transformational leadership. This blueprint created a map which identified and developed these concepts which were then integrated into existing leadership programs. The student development transformational leadership framework, as developed in this study, is a new construct which may significantly impact programs in the future.

A model embracing transformational leadership concepts prepares students with leadership strategies that will enable them to be more effective leaders. Introducing students to these transformational leadership concepts on the undergraduate level may nurture their desires to pursue graduate studies in transformational leadership programs such as the doctoral program offered at the University of San Diego in San Diego, California 
If higher education leadership programs intend to prepare students for leadership in the twenty-first century, theories that utilize transformational leadership perspectives must be included in leadership programs. In developing such a framework for college and university leadership programs, this study makes a significant contribution to leadership education.

\section{DEFINITION OF TERMS}

The following terms are important to this study. STUDENT DEVELOPMENT/STUDENT AFFAIRS - student development and student affairs are synonymous offices and are official divisions of colleges and universities usually headed by a vice president or dean whose interests lie in the non-academic life of the student.

LEADERSHIP - "Leadership is an influence relationship among leaders and followers who intend real changes that reflect their mutual purposes" (Rost, 1990, p. 102).

TRANSFORMATIONAL LEADERSHIP - "When one or more persons engage with others in such a way that leaders and followers raise one another to higher levels of motivation and morality" (Burns 1978, p. 20).

EXPERT PANEL MEMBER - An individual who has some knowledge in transformational leadership and has some professional background in higher education. 


\section{ASSUMPTIONS AND LIMITATIONS OF THIS STUDY}

Through the use of an expert panel, this study identified a set of concepts that would introduce the idea of transformational leadership to undergraduate students in a student development leadership program. In specifying these concepts there is the assumption that there are a set of common ideas that would encompasss the theory of transformational leadership. There is also the assumption that these ideas can be identified by using an expert panel in conjunction with a literature review.

There is the assumption that the individuals who were selected as panel members have some expertise in transformational leadership and leadership training.

It is assumed in this study that there is a particular body of theory based on the writings of transformational leadership scholars. It is also assumed that there are common concepts of transformational leadership that can be derived from these theorists.

This research assumes that a set of transformational leadership concepts can be integrated into existing undergraduate student development leadership programs.

Researcher bias can be a limitation in the study. To diminish the possibility of bias in the data analysis completed, the researcher took special care in the processing of the data. The researcher has also had an active professional career that involves years of experience 
and training in leadership activities and the student development field.

A limitation of this study is the course outlines and syllabi printed in the Leadership Education Source Book (Clark \& Freeman, 1990). There is no way to verify that the course outlines and syllabi listed are actually being implemented as noted in the source Book. The researcher is limited by this fact. Another Iimitation is that these program models solely come from written reports. This makes it difficult to verify that they are being delivered as presented in the Source Book.

Finally, this study assumed that teaching students these transformational leadership concepts, will produce leaders. There is no way to evaluate this and at this time there is no valid instrument that assesses leadership in this way.

The results of the study formulated a framework of transformational leadership concepts that could be integrated in student development leadership programs. This study may not have included all the possibilities that can be developed in order to shape a transformational leadership blueprint. 
CHAPTER II

\section{REVIEA OF THE LITERATURE}

The purpose of this study was to identify concepts related to transformational leadership and introduce a framework that could be integrated into undergraduate college and university student development leadership programs. The methodology followed in this study relied on qualitative emergent methods of research as described in Linstone and Turoff (1975), Guba and Lincoln (1983), Lincoln and Guba (1985), and Patton (1990). These research methods relied on a comprehensive literature exploration of the areas that were investigated in the study.

The overall objective of the literature review was to summarize the literature found in the following four areas. First, a thorough investigation was done on student development leadership programs. A historical perspective was presented leading up to the current status of these leadership programs. Secondly, the whole area of programming and training in the student development field was investigated with a special emphasis placed on leadership program and training. Thirdly, a review of the 
literature on leadership was performed and summarized. Finally, the subject of transformational leadership was researched. Through an extensive investigation of the transformational leadership literature, recurring themes were determined and identified.

The comprehensive literature examination completed in this study was carried out through the review of the major journals, dissertations, scholarly books, papers, and other works concerned with the specific areas investigated.

\section{A HISTORY OF THE CURRENT STATUS OF STUDENT DEVELOPMENT LEADERSHIP PROGRAMS}

The student development profession has had an on-going interest in college and university leadership programs. At their annual convention in 1976, the American College Personnel Association (ACPA) Commission IV, which addresses "students, their Activities and their Community," established the Leadership Task Force for the purpose of investigating the nature of leadership programs in higher education.

During the following four years, this Task Force on Leadership gathered information from various programs and in 1981 published the book, student Leadership in Higher Education. In his opening remarks, editor Dennis Roberts stated that "this book reflects the best collective thinking of colleagues who have expended much of their energy in 
building leadership programs to meet student needs" (1981, p. 3).

Roberts proposed a "Framework for Leadership Development" (p. 213) which was built on the theoretical model of Perry's (1970) cognitive developmental scheme. Perry's theory of intellectual and ethical development was composed of nine stages designed in a hierarchical sequence which started with a dualistic way of thinking, advancing to multiplicity, contextual relativism, and finally commitment in relativism. Perry's framework was constructed from information collected and validated on college students. Roberts used Perry's scheme to assess leaders and describe the differences in their cognitive processes.

Clearly Roberts' work was a pioneering achievement in gathering together the published works of professionals involved in leadership education. But as the topic of leaderstip has been discussed in countless publications since Roberts' work in 1981, the student development profession has contributed few new insights. In the fall of 1989, the National Association of Student Personnel Administrators (NASPA) published a special edited leadership journal. In this journal Gordon and sindon called the Roberts" book "the most comprehensive guide to date for creatively delivered leadership programs in higher education" (1989, p. 85).

Although Roberts' book provided some useful criteria for designing and delivering a variety of college student 
development programs, his understanding of leadership is outdated exemplified by his use of leadership and management in the same sentence as being synonymous. In examining the literature base, Roberts' combined management and leadership literature as being the same (p. I9\& 22). His definition of leadership also encompasses the management arena ( $p$. 211).

Being based on Perry's (1970) developmental scheme, Roberts' (198I) work lacks sensitivity to a woman's way of knowing and understanding. Fried (1989) criticized Perry's work for being completed on male students. She suggested that women's ways of understanding be incorporated into student development programming. The work of Belenky, Clinchy, Goldberger, and Tarule (1986) described cognitive development in women and could serve as such a guide.

In an attempt to remodel Roberts' work, Patrick Brown (1990) noted that a shortcoming of his book was "that it dealt with only those leadership programs created and initiated by student devel cpmental educatcrs" (p. 226). As a result of this critique Brown reported that a renewed study of leadership programs led to the creation of an "Inter-Association Leadership Project which attempted to draw together representatives from various student personnel professional associations in order to update and expand our current thinking about leadership programs" (pp. 226-227).

A partial result of the Inter-Association Project was a "Model Program" statement that the group completed in July 
1989 (Brown, 1990, p. 227). In this statement the group listed seven leadership program core beliefs which revolved around the nature of leadership. The first core belief stated that "Leadership is demonstrated by those individuals designated as leaders and those who participate actively in the organization" (p. 227).

This statement by the Inter-Association Project does not take into account that leadership occurs at all levels and in all types of situations. Calling leadership a "pervasive phenomenon" Denhardt (1981) said that "Leadership should be seen not merely as a position that someone holds, but rather as something that happens in a group or organization, something that comes and goes, something that ebbs and flows as the group or organization does its work (pp. $i x-x)$. Foster (1986) had a similar position when he said "leadership can spring from anywhere; it is not a quality that comes with an office or a person" (p. 187).

The Inter-Association Leadership Project Model Program statement was the last failed attempt of student development professionals to advance a contemporary position on leadership programs. Ann Morgan of Boston College, (personal communication, August 28, 1991) who was one of the original formulators of the Model Program, informed me that the group disbanded due to financial and time constraints that made it difficult for them to meet.

Although the Inter-Association Project offered some resourceful ideas for leadership programs, their assumptions 
about the nature of leadership have had similar shortcomings that are pervasive in the student development literature. A scholarly understanding of leadership is clearly missing in the student development literature.

\section{PROGRAMMING AND TRAINING IN STDDENT DEVELOPMENT}

In discussing whether the function of the student development profession was administrative or educational, Ambler (1989) noted that this debate has plagued the profession with an identity crisis (p. 247). Ambler contended that the profession should have both an administrative and educational function and in fact the educational function justified the existence of student development.

Programming and training have long been a hallmark of the student development profession. Morrill, Hurst, and Oetting (1981) identified "developmental programming" as one of the three specific types of programming performed by the profession. The more recent work of Fried (1989) acknowledged that developmental issues continue to be the emphasis of student development courses. Programming and training are highly valued in student affairs because it contributes to the growth and development of students (Saddlemire, 1988). Participation by students in programming activities has been shown to considerable improve the student enrollment retention rate (Astin, 1985). 
Fried (1989) made an important distinction between training and teaching in her discussion on student affairs programming. She noted the following:

The purpose of training is to help people learn skills to solve problems... The purpose of teaching is quite the opposite--to broaden a person's understanding, to help the person examine a problem from several different points of view, and to place the problem in a cultural and historical context. (p. 355)

For Fried (1989), the challenge facing student affairs practitioners was to be both trainer and teacher.

Crookston (1973) has stated that in student development courses the instructor does more than just relay information. "Depending on the nature of the relationship with the student(s) the teacher could be expert, catalyst, critic, facilitator, mediator, consultant, negotiator, counselor, collaborator and contractor for developmental learning contract (pp. 59-60). Fried (1989) noted that the eclectic background of student development personnel enhances their skills with students. "Access to counseling, consulting, mediation, and group facilitation skills is one of the advantages that student personnel professionals have as instructors" (p. 363).

Schuh (1988) included leadership training in the developmental program category and noted that leadership programs are designed to foster growth. In a survey of 1,331 higher education institutions nationwide, Gregory and 
Britt (1987) reported on 469 such leadership programs. of this group, the student development profession directed the most frequent (27 percent) number of programs. The current Leadership Education Source Book (Clark \& Freeman, 1990) indicated that $30 \%$ of the leadership courses and programs are run by student development offices. In commenting on the program findings cited by Gregory and Britt, Kenneth Clark (1986) stated that "For the most part, (the higher education programs) are management-development and training programs, rather than intellectual explorations of leadership" (p. 19).

Gregory (1986) noted that the student development arena has often been the first area where leadership programs have surfaced and the literature validates this fact. But as Clark (1986) commented, for the most part these programs have missed the mark in leadership education. Cheryl Mabey, Dean for student Development at Mount St. Mary's College in Los Angeles, said that the classical student affairs model "takes students in leadership positions and provides them with training to make them more effective in their organizations". Mabey referred to another more academic type program but "such programs seldom have the objective of developing any Eunctional leadership ability" (Callahan, 1985, p. 3).

College and university leadership programs need the blend of the practical and experiential with the theoretical, which is grounded in sound leadership theory. 
With student affairs so involved with leadership training, there is a definite need for practical ways to integrate the understanding of transformational leadership into the student affairs arena.

The student development profession has a long history with developmental training models. Wood, Wood, and McDonald (1988) found that the integrating of student development theory into the academic classroom resulted in intellectual and developmental growth. A training model for transformational leadership meets the challenges that face student development leadership programs in the future.

\section{LEADERSHIP}

It is not surprising that student development professionals may have been confused in their understanding of leadership for as Burns said "leadership is one of the most observed and least understood phenomena on earth" (1978, p. 2).

A historical look at the leadership literature is useful in understanding how leadership research has evolved. Along with other researchers, Calder (1977) and Chemers (1984) broke leadership studies down into three periods. The first period which focussed on personal attributes and personality traits started around the turn of the century and continued until around world War II. These studies proved inadequate because they inferred that the observance of a particular behavior was a pattern described as 
leadership. Reviewing over one-hundred trait studies, stogdill (1948) found that no consistent patterns existed. Studying the actual behavior of leaders was the next period that went form the 1940s to the late 1960s. This period was highly influenced by the behavioral research that was very popular in psychology and the social sciences. Describing leadership behavior was exciting for a time, but research findings such as Korman's (1966) showed that behaviors had no real relationship with group productivity. Searching for an explanation of leadership processes, the contingency model was first developed by Fiedler (1964), and this contingency approach to the study of leadership has continued from the late 1960 s until the present. Relating the task of the leader to the interpersonal skills and the situation involved, the contingency theory has been the subject of scrutiny as seen in the critique done by Graen, Alvers, Orris and Martella (1970). The result has been that several different contingency models have spun off from Fiedler's (1964) original work. One of these that seems to have made some real contributions to understanding leadership is the transactional approach developed by Hollander and Julian (1970). The transactional approach to leadership "emphasizes the exchange relations between leaders and Eollowers" (Calder, 1977, p. 180). This was an important move to see leadership as part of a social exchange between leaders and followers. 
Distinguishing leadership from management has been a major contribution in leadership studies. Rost (1985) noted that "much of the training going on today under the title of leadership is not leadership training at all, it is management training" (p. 2). Other authors such as Bennis and Nanus (1985), Kouzes and Posner (1987), Palmer (1989), and Zaleznik (1989) confirm the fact that management must be distinguished from leadership.

In his book Leadership for the Twenty-First Century, Rost (1991) argued that the leadership thought and process of the 19th and 20 th centuries are characterized by the industrial paradigm which would be signified by a positivistic, functionalist, reductionistic world view. Rost maintained that we are undergoing a paradigm shift which he terms the postindustrial era. "Postindustrial denotes that the new era is beyond, or more than, or different from the present, industrial era" (p. 100). Many future watchers such as Bell (1973), Bellah et al. (1985, 1991), Harman (1976, 1988), Kahn and Bruce-Briggs (1972), and Senge (1990) would concur that we are on the verge of a postindustrial era.

Rost (1991) defined leadership as "an influence relationship among leaders and followers who intend real changes that reflect their mutual purposes" (p. 102). His book developed this definition and provided an understanding of leadership processes which he said will function in a postindustrial era. 
A significant work that has facilitated a real understanding of leadership was provided by Burns (1978) in his inspirational book on leadership. Exchanging values among leaders and followers and raising consciousness to a higher level of motivation and morality, Burns contributed to the framework of a contemporary understanding of leadership today.

\section{TRANSFORMATIONAL LEADERSHIP}

Tierney (1991) noted that "in general, discussions of transformational leadership always begin with a reference to...Burns' classic study of leadership" (p. 158). Burns (1978) first coined the term "transforming leadership" saying such leadership raises leaders and followers to a higher level of morality and motivation. He specifically stated:

[Transformational] leadership occurs when one or more persons engage [emphasis original] with others in such a way that leaders and followers raise one another to higher levels of motivation and morality... Transforming leadership becomes moral [emphasis original] in that it raises the level of human conduct and ethical aspiration of both leader and led, and thus has a transforming effect on both. ( $p$. 20)

Burns' own study moved the meaning of leadership beyond the trait, behavior, and contingency theories that preceded him 
and influenced leadership theory to a new realm of understanding. Tierney (1991) stated that "Burns' view provides the scaffolding for all other views of transformational leadership" (p. 158).

House (1977) had attempted to explain charismatic leadership in a similar way saying that a leaders goals and behaviors motivated the followers to a higher performance. Bass (1985) applied House' charismatic theory developing a transformational theory on the order of Burns. The difference is that Bass felt that the interaction process between leaders and followers did not necessarily have to benefit the followers. Yukl (1989) used the terms transformational leadership and charismatic leadership referring "to the process of influencing major changes in the attitudes and assumptions of organization members and building commitment for the organization's mission and objectives" (P. 204). Conger (1989), and Conger and Kanungo (1987, 1988), also used the terms transformational leadership and charismatic leadership in similar ways.

While Burns (1978) noted that transformational leadership sought to satisfy higher needs of followers, he felt that most leadership was simply transactional, where leaders appeal to followers self-interest for such things as pay and status. Bass and his associates (e.g., Avolio \& Bass, 1988; Avolio \& Gibbons, 1988; Avolio, Waldman, \& Einstein, 1988; Hater \& Bass, 1988) were involved in making 
clearer distinctions between transformational and transactional leadership.

A careful review of the transformational leadership literature reveals some specific themes recurring in the interpretation of what the process of transformational leadership may include. The remainder of this section will examine these themes.

MORAL, ETHICAL, OR VALUE ORIENTATED

Transforming leadership for Burns (1978) was both moral and morally purposeful (p. 455). Foster (1989, 1991) called for leadership to be both ethical and moral, using these terms synonymously. On the ordar of Burns, Foster (1989) stated that "leadership is founded on the fact of moral relationships; it is intended to elevate people to new levels of morality" (p. 55). Grob (1984) agreed with this thinking, seeing the activity of leadership as intrinsically moral. Barnett et al. (1992) said that the concept of moral and ethical leadership behavior was "a non-negotiable core value [needed] to guide the development of a [leadership] curriculum" (p. 72).

Values in the transformational leadership literature are used in two ways. Avolio and Bass (1988) referred to transformational leadership as value added. Leithwood (1992) concurred, describing value added as "incentive[s] for people to attempt improvements in their practices ( $p$. 9). Peters and Waterman (1982) and De Pree (1989) saw 
values in a similar way as long as the values transformed or improved a particular setting.

A second more common use of values found in the transformational leadership literature links values directly with morals and ethics. In her transformational leadership model, Forbes (1991) used values and ethics interchangeable and found these qualities a foundation to her model. Henrickson (1989) and Hitt (1991) also united the meaning of values and ethics seeing those as crucial factor in the practice of transformational leadership. Tichy and Devanna (1986), and Karelis (1987) concurred that moral responsibility was at the heart of such leadership.

Tierney (1991) could only view leadership as transformational by linking it to a moral component. He stated:

For the assumption that a leader ought not to be compelled to speak out on the moral issues of his or her organization reduces leadership to a set of managerial techniques, and reserves the discussion of moral issues for philosophers and saints. (p. 165) overall, the leadership literature clearly shows the activity of transformational leadership as one that incorporates values, ethics and/or morals in its practice.

\author{
VISION \\ Bennis (1984), Bennis and Nanus (1985), Bennis (1989), \\ and Tichy and Devanna (1986a, 1986b) provided the
}


foundational understanding of vision in transformational leadership.

Bennis (1989) called guiding vision, the "first basic ingredient of leadership" (p. 39). In an earlier work he defined vision as "the capacity to create and communicate a compelling vision of a desired state of affairs, a vision (or paradigm, context, frame - all those words serve) that clarifies the current situation and induces commitment to the future" (Bennis, 1984, p. 66). In their work that involved a five year study of ninety effective leaders, Bennis and Nanus (1985) found that leaders did not develop their visions in private. Rather, the vision articulated was a composite of many individuals the leader had been in association with for awhile. These leaders also had a special ability to communicate their visions.

Yukl (1989) described Bennis and Nanus function of vision in these ways:

One function is to inspire followers by giving their work meaning and appealing to their fundamental human need to be important, to feel useful, and to be of a worthwhile enterprise. A second function of a vision is to facilitate decision making, initiative, and discretion by employees at all levels. (p. 221) Sashkin (1986) did a study of Bennis and Nanus' (1985) work and identified five personality characteristics that could be seen as visionary behavior on the part of leaders. Sashkin also listed three ways in which vision could be 
expressed and explained. His work is a valuable contribution for ways to teach vision and will be discussed more in detail in Chapter $v$.

In a study of 12 organizational leaders, Tichy and Devanna (1986b) found the leaders "visionaries." "Our transformational leaders were able to dream, able to translate those dreams and images so that other people could share them" (p. 32). In doing this Tichy and Devanna said leaders were creating a vision and this concept was an important characteristic of transformational leadership.

Foster (1988) saw vision as a fundamental idea of transformation in leadership and he advocated communicating that to students in college leadership programs. "In kernel form it [transformation] simply says that a leader needs to have a vision for a better future, must communicate that vision in a manner that awakens others, and then must work towards its achievement" (p. 70). Cameron and Ulrich (1986) identified the ability to articulate a vision as an agenda for transformational leadership. Fink's (1990) dissertation was a compelling case study which concluded that vision was an essential component of transformational leadership. In essence, Fink said the process of transformational leadership created change, guided by a communal vision, that was beneficial both ethically and collectively to all the participants. Adams (1986), Roberts (1985), Henrickson (1989), Brandt (1992), Leithwood (1992), are a few other 
authors who concurred that vision is indeed an essential ingredient to the practice of transformational leadership.

\section{CHANGE}

Tichy and Devanna (1986a, 1986b) said transformational leadership was about change and they suggested that leaders identifying themselves as change agents, was a characteristic of transformational leadership. Henrickson (1989) concurred that transformational leaders behaved as change agents. Tichy and Devanna also linked change with vision. They said the change taking place was change that created new visions. Tierney (1991) concurred with the work of Tichy and Devanna affirming that transformational leadership was about "the creation of vision and the mobilization of commitment to change" (p. 159).

Cameron and Ulrich (1986) had a similar view and they maintained that transformational leaders "create a readiness for change among their followers, manage the natural resistance to new conditions and new requirements, and articulate a vision of the future that mobilizes commitment and creates successful institutionalization throughout the system" (p. 40).

Foster (1991) stated that transformational "leadership is change, not control, and the change is the movement toward excellence" (p. 10-11). Other researchers who included change as a component of the transformational 
leadership process include Sashkin (1986), Dill and Fullagar (1987), Yukl (1989), and Rost (1991).

\section{EMPOWERMENT AND SHARED LEADERSHIP}

Foster (1988) stated that "When one reads about empowerment, vision, and transformation, it is Burns who should be thanked" (p. 71). Burns (1978) indeed built a strong case for empowerment in his ideas of realizing mutually held goals of both leaders and followers while raising one another to higher levels of motivation and morality. Hitt (1990) explained that Burns' idea of empowerment moved transformational leadership beyond transactional leadership. "Transformational leadership relies on empowerment as its principle means of motivation" rather than the transactional "carrot and stick approach to motivation" in terms of rewards and punishments (p. 164).

Feminist scholars as Astin and Leland (1991) have built on these ideas and offered a view of leadership grounded in empowerment and the collective action of individuals. Their definition of "power as empowerment treats power as an expandable resource that is produced and shared through interaction by leaders and followers alike" (p. 1). The work of Gilligan (1982) and Kellerman (1984) concurred with their views on power.

Forbes (1991) made a significant contribution to these ideas by integrating the feminist perspective in a monograph which introduced her Theory $F$ Transformational Leadership 
model. Referring to the feminine Forbes noted: "I mean that quality that exists in both women and men but which is more congruent with feminist values and the way women experience the world; hence it is more commonly associated with women" (p. 4). Similar to the ideas of Astin and Leland (1991), Forbes (1991) presented a partnership way of leading where power is seen as power with, rather than power over others. Her research found that "women are more comfortable with sharing power with people rather than having power over them," and that "women often prefer the word influence rather than power" (p. 23).

Tichy and Devanna (1986b) saw "transformational leaders [as those who were] "able to empower others to endure the costs of change and be renewed with the new beginnings" ( $p$. 29).

Bennis (1989) explained empowerment "as the collective effect of leadership" and he found empowerment evident when four themes were present in an organization; "people feel significant, learning and competence matter, people are part of a community, and work is exciting" (p. 22-23).

Sergiovanni (1990) stated that in the execution of value-added leadership "Empowerment is practiced when authority and obligation are shared in a way that authorizes and legitimizes action, thus increasing responsibility and accountability" (p. 96).

Barnett et al. (1992), Dill and Fullagar (1987), and Leithwood (1992) spoke of shared leadership as a collective 
action where participants work together to build a vision. Leithwood saw such power as "consensual and facilitative in nature" (p. 9). Fenrickson (1989) called for organizations to have shared understandings of the mutual purposes of both leaders and followers while Peters and Waterman (1982) spoke of influence being exerted by the transformational leader to obtain shared goals of both leader and follower.

\section{SOCIAL RESPONSIBILITY AND DEMOCRACY}

As leadership scholars approach the twenty-first century, Tierney (I991) called for a reevaluation in how we think about leadership. He stated that "leadership involves moral action that promotes democracy" (p. 164), while "democracy concerns those principles that emphasize social justice and empowerment" (p. 163). Viewed from a critical perspective, Tierney made a strong argument that transformational leadership incorporates moral actions that strive for the good and empower others to take control of their lives.

In a similar frame of mind Foster (1989, 1991) emphasized that leadership as transformation is a concern for social justice and "transformational leadership is the ability of an individual to envision a new social condition and to communicate this vision to followers" (Foster, 1989, p. 41). Citing Burns' work Foster (1991) stated;

"Transformation, in his [Burns] view, involves the raising up of followers to new heights of consciousness regarding 
their social situation, and, by so doing, creating expectations that lead to political demands" (p. 14). Foster (1986b) also united empowerment to raising consciousness saying "empowerment...provides the actors themselves with insight and reflection into the conditions of their existence" (p. 21).

Forbes (1991) stressed that transformational leaders value social justice and "They are catalysts for people, designers of new systems and creators of an improved society" (p. 10).

\section{SUMMARY OF THE IITERATURE REVIEW}

The Iiterature review completed here was an essential component of this study. Through a thorough investigation of the literature, a foundation for responding to the research questions was provided. For example, transformational leadership concepts suggested by the expert panel members were compared to the data uncovered in the transformational leadership literature. Such an analysis using the literature review, gave strength and validity to the triangulation methods carried out in this study. 
CHAPTER III

\section{INTRODUCTION}

This study involved the use of an expert panel to nominate transformational leadership concepts that would be necessary to introduce this topic to undergraduates in a student affairs leadership program. The transformational leadership concepts selected by the panel were compared to the current transformational leadership literature. This set of concepts was also compared to the student development college and university leadership program models and syllabi found in the Leadership Education Source Book (Clark \& Freeman, 1990). After reviewing the recommendation of all panelists, panel member's were given an opportunity to reevaluate their original set of designated concepts. Using a qualitative research analysis process, a final set of transformational leadership concepts were then specified. Ultimately, a framework of transformational leadership concepts was developed and this framework specified how these concepts could be integrated into a student development leadership program. 


\section{RESEARCH DESIGN AND METHODOLOGY}

Qualitative research methods were used to examine the data explored in this study. This technique of research falls under the naturalistic paradigm of inquiry which provides a model for how research may be conducted. The use of this research method overturns the restrictions of the scientific paradigm which relies on quantitative research methods (Guba \& Lincoln, 1983).

The qualitative research design used in this study provided the researcher with choices in how to develop the framework for an undergraduate student development leadership program. Patton (1990) advocated using a paradigm of choice in research methods, recognizing that different methods of research were appropriate for different situations. Patton noted that "there is no rule of thumb that telis a researcher precisely how to focus a study", and that choices on the researcher's part should not be viewed as good or bad, "but choices among alternatives, all of which have merit" (1990, p. 38).

The transformational leadership concepts presented in this study were developed through recommendations submitted by an expert panel. The methods used to gain feedback from the panel of experts were developed through the use of qualitative research techniques which combined the Delphi Technique (Iinstone \& Turoff, 1975) and the Focus Group Interview (Patton, 1990) method. 
The research design followed in this study relied on the triangulation process that added strength to the study by using a combination of methods to specify and develop the framework of concepts. Patton noted that "in each case the (triangulation) strategy involves checking findings against other sources and perspectives" (1990, p. 470). This study developed the triangulation process through the following methods.

The use of an expert panel to identify transformational leadership concepts provided the first triangulation process. Denzin (1978) termed the use of several different evaluators as "investigator triangulation." This method of feedback enhanced the study since a variety of perspectives was obtained as the individual concepts were identified by the panel. The formulation and procedures of the expert panel will be explained in the following section.

The current literature on transformational leadership provided the second piece of the triangulation process. By investigating the interpretation of a variety of theories or perspectives on transformational leadership as it applied to the specified concepts, a triangulation process occurred which Patton (1990) called a "theory/perspective triangulation."

The final triangulation process occurred as the identified concepts and transformational leadership literature were compared to the course outlines or syllabi found in the nineteen student development leadership courses 
and programs listed in the Leadership Education Source Book (Clark \& Freeman, 1990). The source Book provided models of leadership student development theory and praxis through which the findings could be examined.

The qualitative research methods used in this study added strength to the research design since they aimed at interpreting the data and giving understanding versus the predictive aim of quantitative research design.

\section{RESEARCHER AS INSTRUMENT}

As in any qualitative inquiry, I was the instrument of the study. Thus the validity of the study depended on $m y$ own skill and competence. As the instrument of the study, I based my skill and competence on my professional and educational background. My professional experience involved student development work at three different universities. This included work in residence life, student activities, student programming, and admissions. A great deal of interaction revolved around empowering student management skills and leadership potential. More specifically I worked as a team member developing and implementing a new undergraduate student development leadership program. My years of working with college students has given me insight into their developmental process and developmental needs. My undergraduate BSN degree at Marymount College introduced me to statistical studies and research. These techniques were refined during my master's degree program in 
Higher Education Administration at St. Louis University. During my studies in the doctoral program at the University of San Diego, I have learned qualitative research techniques which included the design and implementation of qualitative studies.

\section{THE METHODOLOGICAL TECHNIQUE}

It was difficult to utilize an expert panel for this investigation because this method of design has not been clearly defined in the qualitative research literature. Linstone \& Turoff (1975) specifically made use of an expert panel in laying out the Delphi method of research while Patton (1990) made use of a panel in a similar way in the Focus Group Interview process.

The Delphi Technique recognized the "need to structure a group communication process in order to obtain a useful result" (Linstone \& Turoff, 1975, p. 5). The most common method referred to as the "Delphi Exercise" used the technique whereby individuals are asked to respond on paper to a questionnaire sent to them and then return it to the researcher. After compiling the results, the researcher gives the respondent group at least one more chance to reevaluate their original answers.

By allowing panel members to respond on paper, the process "provides the individual with the greatest degree of individuality or freedom from restrictions on his expressions" (Linstone \& Turoff, 1975, p. 7.). Both the 
Delphi Technique and the Focus Group Interview specified that participants be allowed to hear other responses and make additional comments.

The Focus Group Interview (Patton, 1990) is a similar research method to the Delphi Technique (Linstone \& Turoff, 1975), in that it also seeks to structure a group communication process. Patton described this research method as "an interview with a small group of people on a specific topic" (1990, p. 335). He stated the interview "is not a discussion, it is not a problem-solving session, it is not a decision-making group" (1990, p. 335). This research technique simply gathers recommendations from individuals.

As qualitative research designs, both the Delphi Technique (Linstone \& Turoff, 1975) and the Focus Group Interview (Patton, 1990) facilitated an emergent inquiry process to take place in the study. This emergent process allowed for the research techniques utilized in the study to take on a degree of flexibility and openness. Such a design was the method of choice for this study because it provided research versatility which is not possible with the quantitative scientific methods of research. The emergent process method of research employed by this study facilitated a "discovery orientated approach" which allowed for the student development framework of transformational leadership concepts to emerge (Patton, 1990, p. 41). 


\section{EXPERT PANEL SELECTION}

Choosing the panel members was a process by itself. Linstone and Turoff defined experts as "those who have an applicable specialty or relevant experience" (1975, p. 68). They indicated that it is legitimate to identify experts in a particular area and ask them to recommend candidates who could be used.

The panel members chosen for this study were selected from a group of professionals who had shown some knowledge of transformational leadership or who had been identified by a transformational leadership scholar as an individual who practiced a transformational style of leadership. The following criteria were used in the selection of panel members:

1. Each individual should have published in the area of transformational leadership or been identified by a transformational leadership scholar as an individual who practiced a transformational style ò leadership.

2. Each individual should have some professional background in college or university work.

3. Preference would be given to individuals with student affairs/student development experience.

4. Preference wouid be given to individuals with knowledge or experience in college and university leadership programs. 
5. Preference would be given to individuals who had worked with traditional undergraduate students. student affairs, student development and transformational leadership literature was examined for individuals who met a specified criterion. These individuals provided a pool from which a panel was selected. Investigating the literature base revealed other sources in which to select panel members. Professional groups and conferences pertaining to leadership were two of these sources. For example, The Center for Creative Leadership, a non-profit leadership training and research organization, surfaced throughout the literature review. This organization provides on-going conferences on leadership. Persons involved with the Center were targeted as potential expert panel members. In addition, scholars in transformational leadership were identified and asked to nominate individuals who conditionally met the criteria specified.

These investigative methods led to a group of thirty individuals being identified who met the specified criterion. These individuals were solicited with a letter from the researcher stating the purpose of the research, as well as their role as panel members if they chose to participate (see Appendix A). Individuals who agreed to be considered as panel members were asked to return a background questionnaire sheet which asked about their knowledge base of transformational leadership, their 
knowledge of college and university student

affairs/development leadership programs, and their experience working with traditional undergraduate students (see Appendix B). This information was used to select expert panel members as outlined in the criteria for the selection of panel members.

\section{PANEL SIZE}

Specifying the number of experts was the final process to be accomplished in creating the panel. An expert panel size is unique in that it does not attempt to achieve the results accomplished by random probability samples, but rather strives for more in-depth analysis. Patton noted that "there are no rules for sample size in qualitative inquiry," and that "in-depth information from a small number of people can be very valuable" (1990, p. 184). Patton stipulated that the sample size be judged in context with the design of the study.

In the use of an expert panel for this study, the researcher attempted to gather recommendations on concepts to be used in the framework. This was similar to the process of the Focus Group Interview (Patton, 1990) which gathered information in a related manner. Since the two processes are parallel in their use of a panel, Patton's recommendation of six to eight individuals was the target number of panel members established for this study. 
DEVELOPING THE INITIAL QUESTIONNAIRE

The initial questionnaire was constructed to support the research questions that were developed for this study. In this questionnaire the selected expert panel members were asked: "What transformational leadership concepts do you say are necessary to introduce and integrate the topic of transformational leadership to traditional undergraduates (ie., 18-21 $\mathrm{y} / 0$ ) in a student affairs/development leadership program?" (see Appendix C). Panel members were asked to list at least five concepts and were given the opportunity to add additional concepts if they desired.

\section{DEVELOPING THE FOLLOW-UP QUESTIONNAIRE}

The creation of the follow-up questionnaire also supported the research questions. The concepts recommended by each expert panel member in the initial questionnaire were compiled by the researcher. These results were analyzed and arranged under separate categories isolating the recurrent concepts. For instance, vision was listed by four panel members on the initial questionnaire and their responses were put under one category labeled, "Vision." The concept of trust was listed by only one panel member, but still listed as its own category labeled, "Trust." By compiling the responses in this way, every recommendation listed by a panel member was represented. A total of nineteen different concepts were identified each with its own category. 
The nineteen categories of concepts recommended by the expert panel members were then checked with the transformational leadership review of the literature. Through this triangulation process, the panel members responses were compared with the literature on transformational leadership. This process allowed for any concepts omitted by the panel to be identified. This investigation resulted in no additional concepts being found. If additional concepts had been identified through the literature review, they would have been 1 isted in the follow-up questionnaire.

The follow-up questionnaire was introduced by a cover letter and separated into four parts (see Appendix G). Through a combination of the Delphi Technique (Iinstone \& Turoff 1975) and the Focus Group Interview (Patton 1990), each part was developed in order to encourage feedback and recommendations from each panel member. Part I included the listing of each panel member's responses to the question: "What transformational leadership concepts do you say are necessary to introduce and integrate the topic of transformational leadership to traditional undergraduates (ie., 18-21 $\mathrm{y} / 0$ ) in a student affairs/development leadership program?" (See Appendix F) In order to maintain anonymity as specified by the Delphi study, all panel members responses were listed and referred to by numbers. A panelist's own set of concepts were indicated with an asterisk. 
Figure 1 Follow-up Questionnaire Likert Scale Ranking.

For each statement below, circle the letter which most reflects your position on whether or not the concept should be included in the leadership program.

a..... Agree that it should be included

b...... Not certain, but willing to consider including this.

c..... Disagree that this should be included.

PANEL MEMBER \# 1

1. Listening ability

a b c

2. Personal vision development

a $\quad$ b $\quad c$

Beside each concept listed by a panel member was a nonnumerical three point likert type scale as illustrated in the example in Figure 1. The panelists were asked to circle whether they agreed, were not certain, or disagreed that the concept should be included in the leadership program. The points were specified as: (a) Agree that the concept should be included; (b) Not certain, but willing to consider the concept being included; and (c) Disagree that the concept should be included. Adequate space was left below each concept for comments. The panelists who disagreed with a specific concept were asked to comment why they thought the concept did not fit or how they would like it amended. This initial whole process of Part I, gave panel members the opportunity to assess their own responses in light of the other panel members' responses.

Part II of the follow-up questionnaire listed an individual panel member's responses to the question on what should be taught in a leadership program (See Appendix I). 
Each panel member was given an opportunity to reevaluate his or her own recommendations after seeing the responses of the other six panel members. This method enabled the members to modify and reevaluate their responses. Additional space was provided for further information. This process performed in Part I built upon the exercise that had been completed in Part I and allowed for any new responses to be made by panel members in light of their assessment. In Part II, panel members were now given an opportunity to change their own responses in light of their assessment.

After completing the reevaluation of their own responses in Part II, panel members were asked to complete a second analysis on this page. Boxes had been provided beside each concept listed. In those boxes the panelists were asked to give the sequence in which their concepts should be taught to traditional undergraduate students in a leadership program. This information was useful in developing the final framework proposed for undergraduate student leadership programs.

Part II of the follow-up questionnaire listed the original recommendations of the panel member (see Appendix J). The individual was asked to first make any changes on that page that had been made on the previous page in Part II. Under each concept, the panel member was then asked to describe ways in which that concept could be best communicated to undergraduate students. Panel members were urged to be creative as possible. Ample space was provided 
under each concept for a response. This process made use of the panel members' expertise in instructional design for undergraduate students. These responses proved to be very valuable in formulating the final framework created for this study .

Part IV was the final section of the follow-up questionnaire (See Appendix K). On this page the panel members were asked to list any books, journals, articles, videos, or references of any kind which they felt could be helpful to the understanding of leadership or helpful in implementing an undergraduate leadership program. The resources listed on this page proved to be effective in enhancing the final transformational leadership framework developed for this study.

\section{METHODOLOGY AND DOCUMENTATION PROCESS FLON}

Figure 2 specifies the Methodology and Documentation Process Flow. This diagram denotes the complete processing steps used in the development of the questionnaires and methodology procedures followed for this study.

The thirty individuals who were targeted as potential panel members were sent the first mailings and asked to respond within four weeks. One of the mailings was returned because of an incorrect address. Twelve individuals responded declining to be panel members. Two responded with only a part of the information that was requested. 


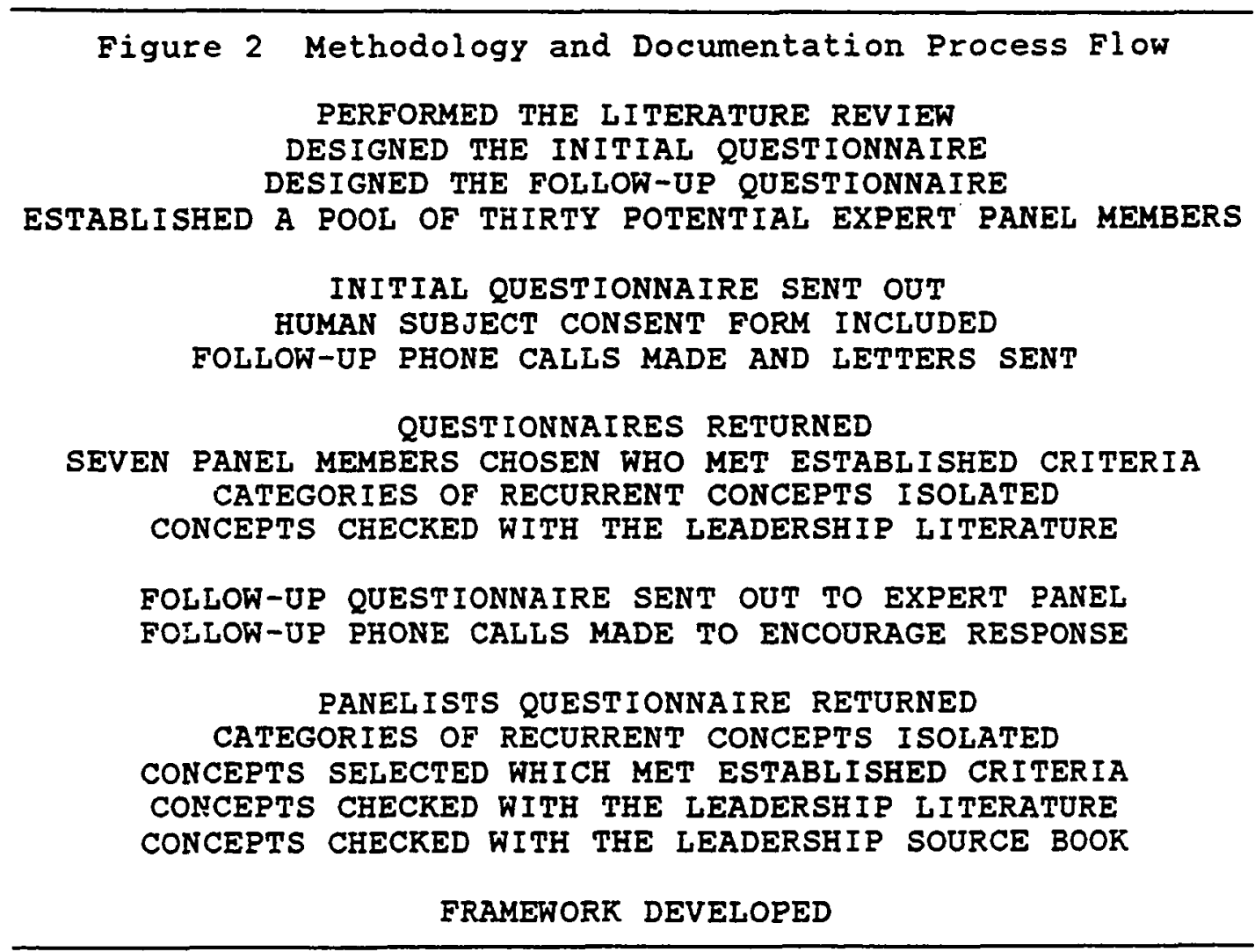

Two consented to be panel members and returned all the completed forms.

Thirteen individuals remained who had not responded within the four week time feriod given and a follow-up phone call was made to each. The researcher spoke directly to the individual or messages were left asking each to respond to the first mailing. One individual could not be reached. A duplicate mailing was sent to the twelve who were contacted. of those twelve contacted, three individuals declined to participate, and three did not respond at all. Five of the six responded and returned fully completed forms. 
The result was that a total of seven individuals completed and returned all the forms requested. Each completed a formal Consent Form indicating that they understood the purpose of the study, that their participation in the study was completely voluntary, and they were made aware of the anonymity details of the panelist process utilized by the Delphi Technique (Iinstone \& Turoff 1975). They also designated whether or not they wanted their names to remain anonymous in the completed dissertation study (see Appendix D).

\section{DATA ANALYSIS AND IMPLICATIONS}

The objective of this study, to propose a framework of transformational leadership concepts for undergraduate college and university student development leadership programs, was met by closely following the qualitative research techniques designed for this study.

In the initial questionnaire the researcher received recommendations from each panelist specifying what concepts should be used in a college or university student development leadership program. These recommendations were sent back to each panel member in the follow-up questionnaire and panel members were allowed to change their original recommendations with respect to the opinions of the rest of the panel. The panel member's final recommendations were arranged under the original nineteen categories of concepts that had been established. For example, vision had 
been listed by four panel members on the initial questionnaire and these responses were listed under one category labeled, "Vision." On the follow-up questionnaire, the same four panel members included vision in their final recommendation. But the three remaining panelists also listed vision in their final recommendation as a concept that should be included in the framework. Thus the concept of "Vision" ended up being recommended by all seven panel members.

Two new categories of concepts were isolated in the follow-up questionnaire and two categories of concepts were deleted. Ultimately, nineteen categories of concepts were established by isolating the recurrent concepts listed by the panelists.

The qualitative research methods used in this study gathered recommendations from panel members as to what concepts should be included in a college and university student development leadership program. There was no attempt to reach a consensus of the panel members' opinions. Patton (1990) noted that this type of research technique specified by the "Focus Group Interview," simply tries to gather recommendations from individuals. Thus the final responsibility of the concepts used in the framework remained solely with the researcher.

The researcher examined the nineteen categories of concepts that were isolated from the panelist follow-up questionnaire list of responses. In order to avoid bias by 
the researcher, concepts listed by four or more panelists were selected for the framework. These concepts were checked to make sure that no panelist had disagreed that the concept should be included in the final blueprint. This resulted in four concepts being identified.

These four identified concepts were examined with the current transformational leadership knowledge base as described in the "Review of the Literature" found in Chapter II. By examining each concept with the theories of transformational leadership literature, a triangulation process occurred which Patton (1990) called a "theory/perspective triangulation." In interlinking these concepts with the transformational leadership literature, the results provided an understanding that the data collected and used was consistent and reliable. Finally, the four identified concepts were examined with the nineteen college and university student development leadership courses and programs listed in The Leadership Education Source Book (Clark \& Freeman, 1990). A triangulation process occurred as the four concepts were compared to the course outlines and syllabi listed for each program. The concepts were examined with the student development theory and praxis as described by each program. This analysis verified whether or not these four concepts were included in the nineteen college and university leadership programs. 
The concepts selected to be used in the actual framework were thus determined by the following criteria:

1. The concept was Iisted by at least four of the seven panel members.

2. No other panelist had disagreed that the concepts should be included in the framework.

3. The concept was found to be included in the transformational leadership literature review.

POTENTIAL CONCERNS OR LIMITATIONS IN THE RESEARCH

Patton (1990) noted that "the human factor is the greatest strength and fundamental weakness of qualitative inquiry and analysis" (p. 372). With this in mind I started this research project being concerned that my own bias could effect the outcome of the study. When I began this project I assumed the transformational leadership knowledge base as I knew it, was not being taught in student development leadership programs. Fink (1990) addressed this problem suggesting that the researcher approach the project willing to take on the risk of being proven wrong. I strived to undertake this project with the same mind set.

Solicitation of individuals to be panel members proved to be a concern. The results of the framework of concepts could be effected by panel members who may have had tenuous knowledge of the area investigated. Care was taken to select individuals who had proven expertise in the areas being investigated. 
Participation motivation of the selected panel members also proved to be a concern. Care was taken to have attractive questionnaires requiring only about thirty minutes to complete. Obtaining permission to use the University of San Diego, School of Education letterhead contributed to the validity of the project and gave the questionnaires a more professional appearance. The researcher stayed on strict self-imposed time lines through follow-up phone calls and letters to encourage returns. This resulted in all seven panelists returning their followup questionnaires. Some panelists could have definitely taken more time to offer comments and complete the questionnaires more thoroughly, but understanding the human condition the researcher was prepared for what emerged.

The qualitative designs of the Delphi Technique and the Focus Group Interview Process enhanced the quality of the study by providing careful techniques for gathering and analyzing data. Combining these two research methods allowed the project to emerge keeping the credibility of the study sound. The Delphi Technique provided the techniques to structure the group communication process whereby individuals respond on paper to a questionnaire and are given a chance to reevaluate their original answers. The anonymity of the Delphi Technique assured that panelists would not be biased or coerced by others.

The Focus Group Interview provided the techniques to gather information from a small group of people and 
justified the fact that the researcher can simply gather recommendations and need not get a consensus from the group. Both techniques were enhanced by the strong triangulation procedures which strengthened the truth and validity of the research design. 


\section{CHAPTER IV}

\section{FINDINGS OF THE STODY}

The findings of this study are based on the responses of a panel of experts. The panel was composed of seven individuals who demonstrated an expertise in the meaning of transformational leadership. Six of the panel members represented institutions of higher education throughout the United states and the final member was employed by a national non-profit leadership research and training group. These seven experts participated in a qualitative study that combined the research methods of the Delphi Technique (Linstone \& Turoff, 1975) and the Focus Group Interview (Patton, 1990). These research techniques were developed and required that panel members respond to two separate questionnaires. In the end, a final set of transformational leadership concepts were produced. There transformational leadership concepts were integrated together and a framework was constructed specifying what should be taught in an undergraduate student development leadership program. 
PANEL SELECTION AND METHODOLOGICAL RESULTS

Demographic data was obtained from information requested from all panel members on the initial questionnaire. The expert panelists chosen for this study were selected from a group of thirty professionals who had published in the area of transformational leadership or who had been identified by a transformational leadership scholar as an individual who practiced a transformational style of leadership.

Potential panelists were required to return a completed background questionnaire sheet which asked about their knowledge of transformational leadership, college and university student development leadership programs, and their experience working with traditional undergraduate students (see Appendix B). The selection of expert panel members included the following criteria:

1. Each individual should have published in the area of transformational leadership or been identified by a transformational leadership scholar as an individual who practiced a transformational style of leadership.

2. Each individual should have a professional background in college or university work.

3. Preference would be given to individuals with student affairs/student development experience. 
4. Preference would be given to individuals with knowledge or experience in college and university leadership programs.

5. Preference would be given to individuals who had worked with traditional undergraduate students. out of thirty individuals contacted, seven completed and returned all the forms requested on the initial questionnaire and these seven met the criteria specified for selection as expert panel members. This team of three women and four men came from institutions which were from diverse geographic locations across the U.S. (see Figure 3). Six panelists indicated on a Consent Form that their names could be used in the completed dissertation study (see Appendix D). The remaining panel member asked that his name remain confidential.

Qualitative research methods which combined the Delphi Technique (Linstone \& Turoff, 1975) and the Focus Group Interview (Patton, 1990) were used to develop the initial questionnaire and follow-up questionnaire sent out to the panel members. The initial questionnaire consisted of a cover letter (see Appendix A), a background information questionnaire (see Appendix B), a transformational leadership concepts nomination sheet (see Appendix C), a human subjects consent form (see Appendix D), and a stamped self-addressed envelope. This packet was mailed to the thirty potential panelists on June 15, 1992 and they were requested to return the completed materials by 


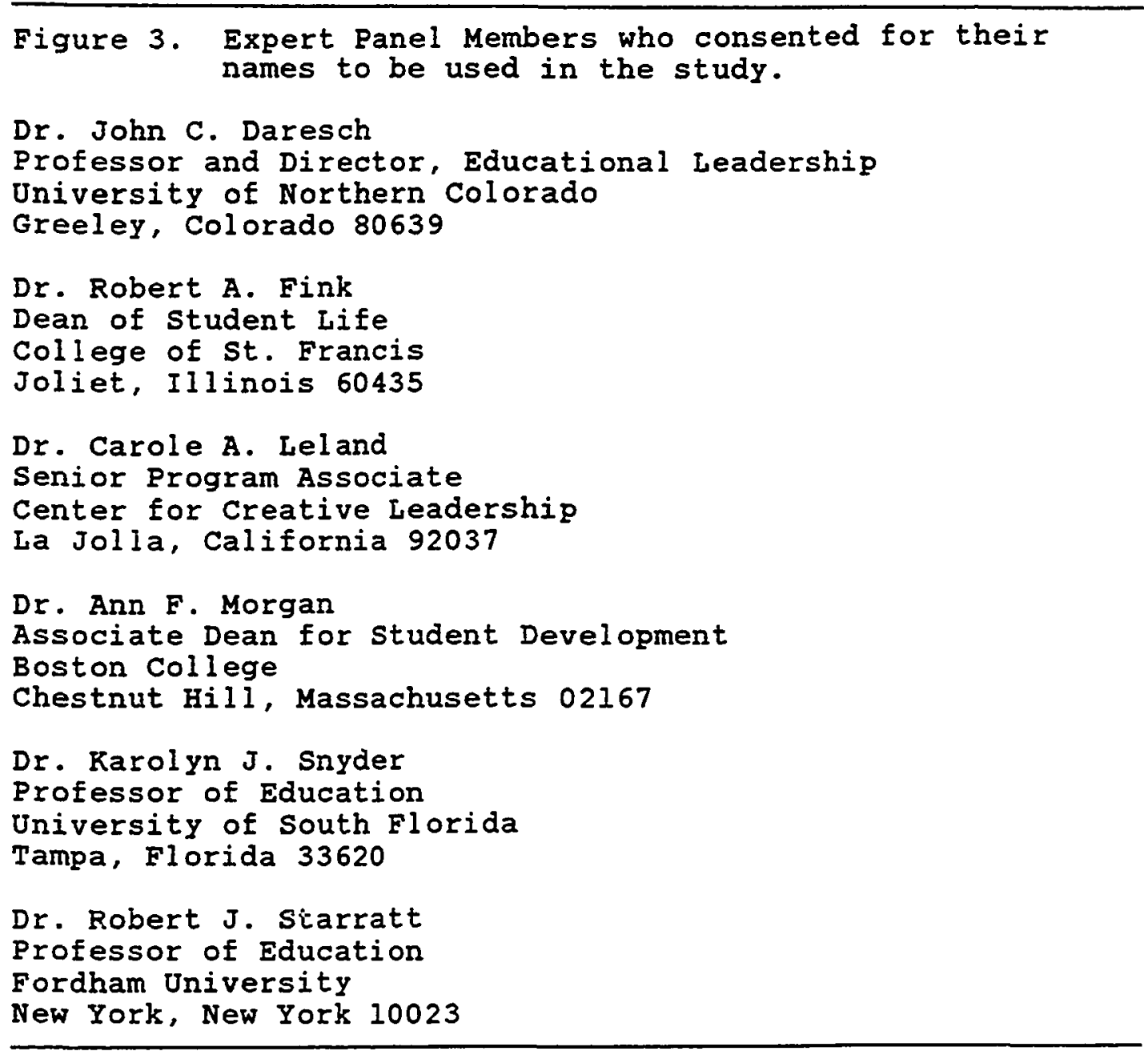

August 1, 1992. In the cover letter panelists were given an opportunity to decline participating in the study by simply signing their names in the space provided and returning that sheet in the self-addressed envelope. By the return deadline, ten panelists had declined to take part in the study. Although participants were not asked to give a reason for declining, three stated they did not feel their background was sufficient and five noted they were already 
overextended in commitments. Six individuals returned materials consenting to be panel members. Three of these individuals were rejected as panelists since they failed to nominate transformation concepts to be used in the framework. These individuals were sent letters stating that they did not meet the criteria established for the dissertation (See Appendix E). Two panel packets were returned to the researcher due to incorrect addresses. Follow-up phone calls were made to the twelve remaining panelists who missed the return deadine. A duplicate initial questionnaire packet was sent to this group. Four individuals declined to participate, four did not respond at all, and four consented to be panelists and returned all the materials completed. The initial questionnaire process was completed with seven individuals being selected as expert panel members. On August 25, 1992 a letter was sent to these individuals informing them that they had met the panel selection criteria established in the dissertation and had been chosen as expert panel members (See Appendix F). The follow-up questionnaire was developed with the responses received from the panelists and the questionnaire was divided into four parts. In Part I panel members were asked to respord to the thirty-five transformational leadership concepts they had nominated to be used in a student development leadership program (see Appendix H). In Part II panel members were given the opportunity to reevaluate their own recommendations after seeing the 
responses of the other six panel members. After completing the reevaluation panelists were asked to give the sequence in which concepts should be presented to undergraduate students in a leadership program. (see Appendix I). In Part II the panel members were asked to describe the ways in which each of the recommended concepts could be best communicated to undergraduate students (see Appendix J). In Part IV, the final section of the follow-up questionnaire, panel members were asked to list any references that could be helpful in the understanding of leadership or helpful in implementing an undergraduate leadership program (see Appendix K). The follow up questionnaire packet was sent out on september 21, 1992 with a cover letter asking that the materials be returned no later than october 1, 1993. Follow-up phone calls were made to three panelists not meeting that deadline. The follow-up questionnaire was ultimately returned by all seven expert panel members.

\section{INITIAL QUESTIONNAIRE RESULTS}

The initial questionnaire was constructed to support the research questions that were developed for this study. In addressing the first research question expert panel members were asked: "What transformational leadership concepts do you say are necessary to introduce and integrate the topic of transformational leadership to traditional undergraduates (i.e., 18-21 $y / 0$ ) in a student affairs/development leadership program?" (see Appendix C). 
Panelists were asked to list at least five concepts and were given the opportunity to add additional concepts if they desired. Each of the seven panelists listed five different transformational leadership concepts, no additional concepts were nominated (see Appendix $H$ ). The researcher analyzed and arranged these results under separate categories isolating nineteen recurrent concepts and these are presented in Table 1 . For example, empowerment was listed by five panel members as a transformational leadership concept and their responses were put under the one category labeled, "Empowerment." The concept of change was listed by only one panelist, but this was still listed as its own category labeled, "Change." By compiling the panelist responses in this way, every recommendation listed by a panel member was represented.

The nineteen categories of isolated concepts were then compared to the current literature on transformational leadership found in Chapter II. This analysis answered the second research question which asked if the nominated concepts were found in the current transformational leadership literature? This investigation reflected much of what is said about transformational leadership in the Iiterature. However, the panelists identified additional categories that they felt were relevant and should be included in the transformational leadership program. 
Table 1 Recurrent Transformational Leadership Concepts CONCEPT PANEL MEMBER TOTAL NUMBER

Empowerment II-III-IV-VI-VII 5

vision

$I-I I-I V-V I$

4

Values/Ethics

I I-V-VI-VI I

4

Shared Power/

$I-I V-V I$

3

Leadership

Social

$V-V I$

2

Responsibilityl

Democracy

Iistening Ability I-IV

2

Communication skill

Hope III-VI 2

Change

II

1

Faith in Humanity III 1

Motivation

V I

Institution

$\mathrm{V}$

1

Building

Heroism

1

Trust

VII

1

Development VII

1

Flip flop who is

II

1

leader/fol lower

Integrity

I I I

1

Service

II I

1

InEluence

VII

1

Foll owership

I I

1

Note: $N=7$ respondents 


\section{FOLLOW-UP QUESTIONAAIRE RESULTS}

The follow-up questionnaire was also constructed to support research questions one and four, and the questionnaire was separated into four parts. Each part was developed to encourage feedback and recommendations from the seven panel members. The research results on the follow-up questionnaire are presented in the following manner.

\section{PART I - QUESTIONNAIRE RESULTS}

Part I included the listing of each panel member's responses to the question: "What transformational leadership concepts do you say are necessary to introduce and integrate the topic of transformational leadership to traditional undergraduates (ie., $18-21 \mathrm{y} / 0$ ) in a student affairs/development leadership program (see Appendix H). For each statement listed, the panelists indicated their position whether or not the concept should be included in the leadership program. All panel members were listed and referred to by numbers in order to maintain anonymity as specified by the Delphi Technique. A panelist's own set of concepts were indicated with an asterisk. A non-numerical three point likert type scale was used beside each concept (see Figure 1, Chapter III). The panelist circled whether they agreed, were not certain, or disagreed that the concept should be included in the leadership program. The points were specified as (a) Agree that the concept should be included; (b) Not certain, but willing to consider the concept being included; and (c) Disagree that the concept 
should be included. A summary of the panelists responses is presented in Table 2. Adequate space was left below each concept for comments. Panelists were specifically asked to comment on any concept they disagreed should be included in the leadership program.

Although only a few comments were made by the panelists in Part $I$, those remarks proved to be helpful in understanding the responses. For instance, the one panel member who disagreed that the concepts of integrity, faith in humanity, and hope should be included in the leadership program noted that all three "should be present prior to admission to a program." Another panelist who was not certain about the concept of hope, stated that the concept should be included into a larger construct. Two panelists disagreed with the concept of heroism. One said it was a "male-masculine approach" and the other noted it was "sexist language-what's really the core here?" It is interesting to note that both of these panelists were women and the concept of heroism had been nominated by a man.

It appeared that the semantic construction of certain panelists responses provided interpretation problems for some panel members. For example, one panel member listed as a concept: "Empowerment---What does it mean?" This panel member circled "Not Certain, but willing to consider including this concept" to another panel member's nominated concept stated: "Empowering others to tackle challenges." In another instance a concept was stated: "Not related to 
Table 2 Panelists responses to whether or not concepts should be included in the leadership program.

\begin{tabular}{|c|c|c|c|}
\hline CONCEPT & Agree & Not Certain & Disagree \\
\hline Empowerment & 6 & 1 & 0 \\
\hline Vision & 7 & 0 & 0 \\
\hline Values/Ethics & 6 & 1 & 0 \\
\hline $\begin{array}{l}\text { Shared Power/ } \\
\text { Leadership }\end{array}$ & 6 & 1 & 0 \\
\hline $\begin{array}{l}\text { Social } \\
\text { Responsibility/ } \\
\text { Democracy }\end{array}$ & 7 & 0 & 0 \\
\hline $\begin{array}{l}\text { Listening Ability } \\
\text { Communication Skill }\end{array}$ & 3 & 4 & 0 \\
\hline Hope & 5 & 1 & 1 \\
\hline Change & 6 & 1 & 0 \\
\hline Faith in Humanity & 6 & 0 & 1 \\
\hline Motivation & 6 & 1 & 0 \\
\hline $\begin{array}{l}\text { Institution } \\
\text { Building }\end{array}$ & 3 & 2 & 1 \\
\hline Heroism & 3 & 2 & 2 \\
\hline Trust & 7 & 0 & 0 \\
\hline Development & 6 & 1 & 0 \\
\hline $\begin{array}{l}\text { Flip flop who is } \\
\text { leader/follower }\end{array}$ & 3 & 4 & 0 \\
\hline Integrity & 6 & 0 & 1 \\
\hline Service & 5 & 2 & 0 \\
\hline Influence & 6 & 1 & 0 \\
\hline Fol lowership & 7 & 0 & 0 \\
\hline
\end{tabular}

Note: $\mathrm{N}=7$ respondents 
positions in an organization, but is relational. Flip flopping of who is a 'leader' and who is a 'follower' over time according to contexts." Four panelists indicated they were "Not Certain" about this concept being used in the leadership program. But one panelist noted as a comment that the concept was "not terribly clear, could be stated more directly." These examples indicated that in a few instances, panelists experienced some difficulty in the interpretation of meaning of some responses.

PART II - QUESTIONNAIRE RESULTS

Part II of the follow-up questionnaire was developed to flow from the exercise panel members had just completed in Part I where they assessed all panel members responses. Part II listed an individual panel member's recommendations to the original question of what should be taught in a leadership program (see Appendix I). In light of reviewing the nominated concepts of the other six panelists, the panel members reevaluated their recommendations. On this page panelists could delete any recommendation and add a new one in its place. If panel members wanted to keep all of their original recommendations plus add extra ones, additional space was provided for that purpose.

Three panelists made no changes to their original nominations of what transformational leadership concepts should be taught in a leadership program. However, the remaining four panelists significantly changed their original recommendations. A list of these changes is 
presented in Table 3 . These recommendations were arranged under the original nineteen categories of concepts that had been established. For example, one panel member retained all the original nominated concepts and added two additional ones. Two other panelists added two additional concepts but also made changes to their originally nominated concepts. The panelist who had originally nominated heroism as a concept, deleted that from the final $l$ ist and added the concepts of empowerment and vision to the list. The concept of vision had originally been nominated by four panelists in the initial questionnaire and was added by the three remaining panelists in the follow-up questionnaire. Thus in the end, vision was listed by all seven panel members as a transformational leadership concept to be used in the leadership program. The panelist who had originally included service, faith in humanity, and hope in the original set of concepts removed these from the final set. This panelist then nominated the concepts of: developing followership, building community, and motivating toward a vision. Another panelist expanded the concept of values to include social responsibility. It was apparent that facilitation of the assessment process performed in Part I, had stimulated four panelists to reflect upon their original recommendations. These changes were then reflected in Part II.

In the concluding analysis of panelists responses to final recommendations in Part II, two concepts were deleted 
Table 3 Panelists responses to final concept recommendations CONCEPT

Initial Concepts Recommended
Part II Final Total Recommendations

\begin{tabular}{|c|c|c|c|}
\hline Empowerment & $I I-I I I-I V-V I-V I I$ & $\mathrm{~V}$ & 7 \\
\hline Vision & $I-I I-I V-V I$ & III-V-VII & 7 \\
\hline Values/Ethics & $I I-V-V I-V I I$ & & 4 \\
\hline $\begin{array}{l}\text { Shared Power/ } \\
\text { Leadership }\end{array}$ & $I-I V-V I$ & VII & 4 \\
\hline $\begin{array}{l}\text { Social } \\
\text { Responsibility/ } \\
\text { Democracy }\end{array}$ & $V-V I$ & VII & 3 \\
\hline $\begin{array}{l}\text { Listening Ability } \\
\text { Communication skill }\end{array}$ & $I-I V$ & II I & 3 \\
\hline Hope & III-VI & $(-) I I I$ & 1 \\
\hline Change & I I & & 1 \\
\hline Faith in Humanity & III & $(-) I I I, V$ & 1 \\
\hline Motivation & $\mathrm{v}$ & & 1 \\
\hline Institution Build. & $\mathrm{V}$ & & 1 \\
\hline Heroism & V & $(-) v$ & 0 \\
\hline Trust & VII & & 1 \\
\hline Devel opment & VII & & 1 \\
\hline $\begin{array}{l}\text { Flip flop who is } \\
\text { leader/follower }\end{array}$ & II & & 1 \\
\hline Integrity & III & $I I-V I I$ & 3 \\
\hline Service & I I I & $(-)$ III & 0 \\
\hline Influence & VII & & 1 \\
\hline Followership & II & III & 2 \\
\hline $\begin{array}{l}\text { *Leadership/ } \\
\text { Management }\end{array}$ & II & & 1 \\
\hline *Build Community & III & & 1 \\
\hline
\end{tabular}

* New concept added in Part II Note: $N=7$ respondents 
from the original nineteen categories and two were added (see Table 3). The concepts of heroism and service were deleted because the panelist who originally nominated them removed these concepts from their final recommendations in Part II. Also, no other panelists included these concepts in their final nominations. The concepts of leadership/management and building community were each nominated by one panelist in the final recommendations. Thus these suggestions were added to the categories of concepts. With two categories of concepts deleted and two added, nineteen concepts remained in the final analysis. A compilation of transformational leadership concepts is presented in Table 4.

SELECTING THE CONCEPTS

In order to avoid bias by the researcher the concepts selected to be used in the framework were determined by the following criteria:

1. The concept was listed by at least four of the seven panel members.

2. No other panelist had disagreed that the concept should be included in the framework.

3. The concept was found to be included in the transformational leadership literature review. The nineteen categories of concepts presented in Table 4 revealed that four concepts were listed by at least four of the seven panel members. 


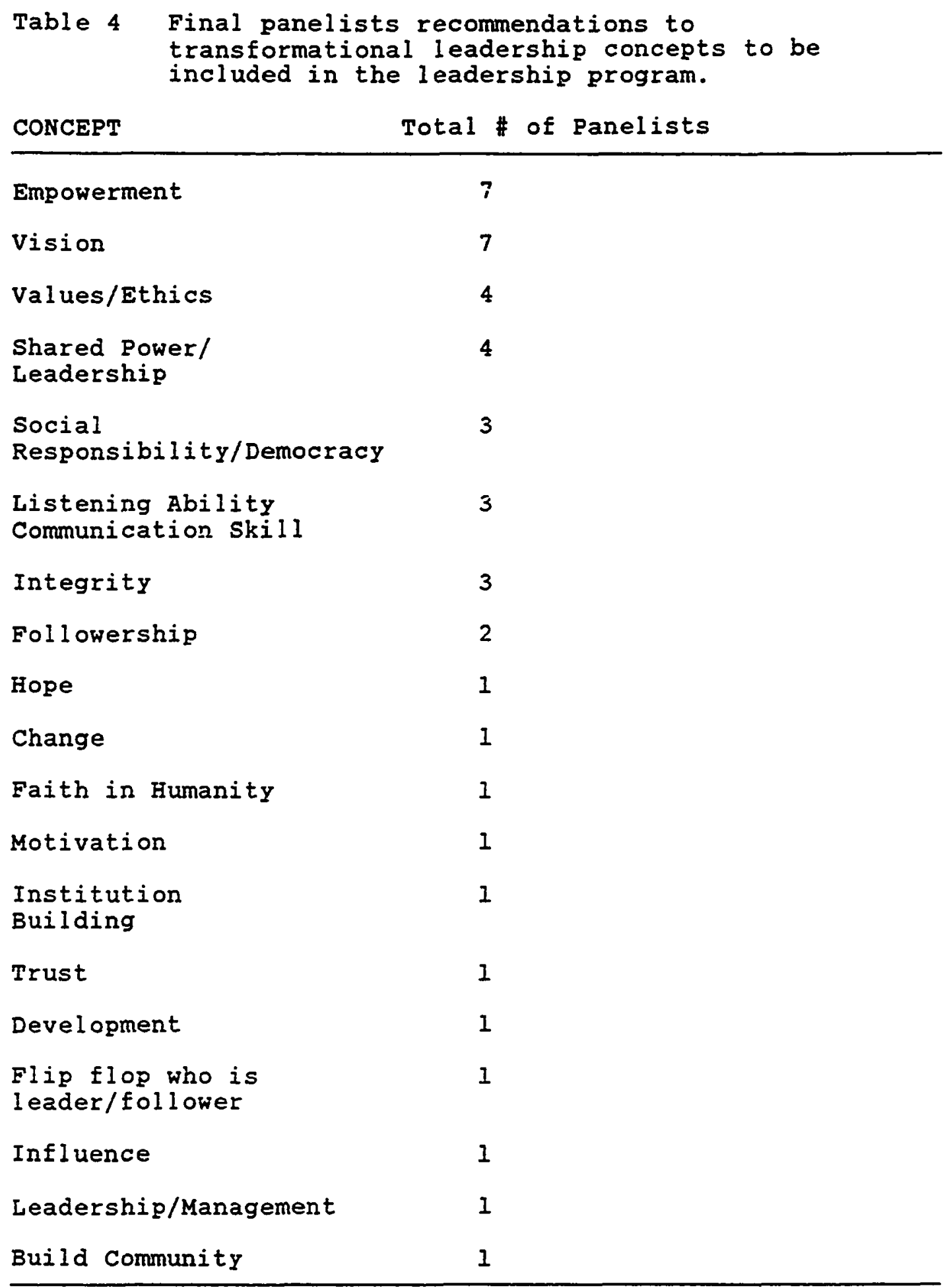

Note: $\mathrm{N}=7$ respondents 
These identified concepts were: empowerment, vision, values/ethics, and shared power/leadership. In reviewing the responses of panelists in Table 2, no panel member had disagreed that these concepts should be included in the leadership program. These four selected concepts were examined with the current transformational leadership knowledge base described in the "Review of the Literature" found in Chapter II. This analysis addressed the second research question and revealed that these concepts were found in the transformational leadership literature. Ultimately, the four concepts of empowerment, vision, values/ethics, and shared power/leadership satisfied the established criteria to be used in the leadership program (see Figure 4).

\section{CONCEPTS EXAMINED FITH STUDENT DEVELOPMENT PROGRAMS}

The four transformational leadership concepts were examined with the nineteen college and university student development leadership courses and programs listed in The Leadership Education Source Book (Clark \& Freeman, 1990). A list of these nineteen schools is provided in Appendix L. This analysis addressed the third research question which asked if the concepts were included in the course outlines or syllabi presented in the source Book. The material provided in the source Book relied on each school to submit information on its leadership program. The details submitted on a school varied from brief outlines of a program to full course syllabi. Each school presented an 
Figure 4. Concepts selected to introduce the topic of transformational leadership in a student development leadershig program.

1. EMPOWERMENT

2. SHARED POWER/LEADERSHIP

3. VISION

4. VALUES/ETHICS

overview, purpose, philosophy, or objective of the program. All included some content of the material to be covered. Half of the schools included a break down of class meetings including the program topics or subjects covered. Six schools i isted the required texts for the course or program while four schools included a bibliography or list of readings.

The four transformational leadership concepts of empowerment, shared power/leadership, vision, and values/ethics were examined with the outlines provided on the nineteen student development leadership courses and programs found in the source Book. Several schools included some of these concepts in their outlines. Values and/or ethics training was incorporated into over half of the institutions as a major topic to be covered. Vision was listed as an important component by two institutions. One school included empowerment as an objective in comprehending 
the leadership process; understanding the notion of empowerment and how to empower others. The concept of shared power or shared leadership was more difficult to assess. It was apparent that four institutions included this topic in some form. Many schools covered gender issues as a topic, but it was not evident whether the feminist perspective of shared power or leadership was included. Even the notion of leaders as followers, which could be considered as shared power, was not found in the outlines. Burns' (1978) book, Leadership was not listed as a source by any course or program. His view of transformational leadership as a process that raised leaders and followers to higher levels of motivation and morality was not found in any of the citings presented by the institutions. Two schools listed transformational leadership as a topic to be covered but it was not clear how the term was being used. Building skills was the program or course objective listed by most all schools. These skilis usually centered around communication and interpersonal relationship techniques. Most courses or programs focused on assisting students in effectively fulfilling leadership roles. Although the four transformationai leadership concepts of empowerment, shared power/leadership, vision, and values/ethics were found in the isolated instances mentioned here, the researcher did not get the sense that the subject of transformational leadership was embraced by any program. 
SEQUENCE IN WHICH CONCEPTS SHOULD BE TAUGHT

After completing a reevaluation of nominated concepts in Part II, panelists were asked to suggest the sequence in which concepts should be taught to undergraduates students in a leadership program (see Appendix I). The panelists were instructed to register their responses in the boxes provided beside each concept.

Five panelists completed this section while the remaining two panelists made no suggestions. The results of the panelists sequence of how concepts should be introduced in a leadership program is presented in Table 5. This information was less helpful to the researcher since the five panelists responses were so varied. There was not a great deal of commonalty in responses. Values and ethics received three recommendations as the first concept to be introduced in the leadership program. But one of the two remaining panelists had not even included values and ethics as a concept and the other one listed it as the fifth concept to be introduced. The concept of vision was consistently seen as being introduced at the beginning of the program. Two panelists listed it as being the first concept to be presented, one as the second concept, and the remaining two panelists as the third concept to be explained. Empowerment was nominated as a concept to be introduced toward the end of leadership studies. Four panelists 1 isted empowerment as the fourth concept to be taught and one as the fifth. 
Table 5. Ranking of five panelist sequence in how concepts should be introduced to students.

\begin{tabular}{lccccc} 
Panel Member & \#II & \#IV & \#V & \#VI & \#VII \\
\hline EMPOWERMENT & 4 & 5 & 4 & 4 & 4 \\
SHARED POWER/LEADERSHIP & $\mathrm{x}$ & 1 & $\mathrm{x}$ & 5 & 6 \\
VISION & 1 & $I$ & 3 & 3 & 2 \\
VALUES/ETHICS & 5 & $\mathrm{x}$ & 1 & 1 & 1 \\
\hline
\end{tabular}

$x$ - Did not suggest concept Note: $N=5$ respondents

The concept or shared power and shared leadership received a varied response as noted in Table 5. Overall, this information may have been of more practical use to the researcher if all the panel members had completed this section of Part II. With two panelists responses missing, it was difficult to establish any consistency to the suggestions.

PART III - QUESTIONNAIRE RESULTS

Part III of the follow-up questionnaire asked the expert panel members to describe ways in which each of their final nominated concepts could be best communicated to undergraduate students. Ample space was provided under each concept and panelists were urged to be creative as possible in their responses. Three of the seven panelists did not offer any suggestions on this page. Two of the panelists who did respond provided general approaches which they applied to all the concepts. One of the panelists said a variety of media modes should be used to introduce concepts 
and that practical leadership experience should be integrated into the program. The other panelist stressed much of the same noting that the leadership knowledge base should be integrated with personal experiences.

The remaining two panelists who answered this section offered specific recommendations under each concept. For example, the ideas provided for the concept of empowerment were characteristic of the typical replies of these two panelists. In addressing empowerment, one of the panelists proposed analyzing an organizational chart focussing on the Elexibility of leadership and followership in the diagram. This experience would be integrated with readings on followership and creativity discussing what place empowerment takes in the relationship between leaders and followers. Another panelist suggested a class project on designing a creative organization where the followers were inanimate objects or drones, then discuss the implications of this on the organization. The other panelists stressed the idea of providing students with opportunities to make personal statements in their essays and projects. These statements would be shared with a larger group of people. This lesson would emphasize the art of listening and appreciating the views of others. The recommendations of these two panel members proved to be very valuable to the researcher. These recommendations were helpful in formulating the final framework created for this study and they are presented more specifically in Chapter $V$. 
PART IV - QUESTIONNAIRE RESULTS

In Part IV, the final section of the follow-up questionnaire, panel members were asked to list any books, journals, articles, videos, or references of any kind which they felt could be helpful in the understanding of leadership of helpful in implementing an undergraduate leadership program. Six of the seven panelists provided at least some type of reference. Most of the sources that were provided centered around familiar leadership works by authors such as Warren Bennis, James McGregor Burns, Max De Pree, Tom Peters, Joseph Rost, Thomas Sergiovanni, and James Vaill. Although one panelist suggested works by Martin Luther King, Ghandi, Tolstoy, and the French philosopher Foucault. Two panelists suggested $\mathrm{Clark}$ and Freeman's (1990) Leadership Education Source Book, which was extensively used for this study. Using videotapes on visioning and paradigms were recommended, although none were specifically named. Two panelists mentioned the film "l2 Angry Men." The resources contributed by the panelists were effective in enhancing the final transformational leadership framework developed for this study and introduced in Chapter v.

\section{RESEARCH ANALYSIS CRITIQUE}

Throughout the methodological process, the researcher closely evaluated the research analysis methods. Acquiring the initial set of transformational leadership concepts from the expert panel nembers appeared to go smoothly. All panel 
members submitted at least five concepts as they were asked to do in the initial questionnaire. In Part I of the follow-up questionnaire there was complete cooperation by the panel members in indicating if other panelists' nominated concepts should be included in the leadership program. At this point there was some disagreement in the semantic construction of responses by various panelists. An example of this is a panelist who nominated empowerment as a concept but was not comfortable with the way another panelist had termed the use of empowerment. The researcher felt that a subsequent questionnaire including these results could have given the panelists an opportunity to srovide further feedback. The researcher however, is not convinced that in the final analysis this may have made any real differences in the results. There still may have been some disagreement on the semantic construction of panelist's responses.

After reviewing and reacting to all panelists responses, the exercise carried out in Part II of the follow-up questionnaire did indicate that some panelists were influenced by this activity. Here panelists were asked to reevaluate their own set of original nominated concepts in light of reviewing the nominated concepts of the other six panelists. The four panelists who changed their recommendations in this section modified some of their responses to include concepts nominated by other panelists. It appeared that the assessment performed in this section 
stimulated a reevaluation and self-critique by the panelists.

In selecting the transformational leadership concepts to be used in the student development leadership framework, the researcher followed a strict criterion. This method was performed in order to avoid bias on the researcher's part. The first criteria stated that a concept had to be listed by at least four of the seven panel members to be included in the final draft. In retrospect, this criteria may have been too stringent. A review of Table 4 which displays the number of panelists who nominated each concept shows that three additional concepts would have been included in the framework if the criteria for a concept was reduced from four to three panelists. Of the three additional concepts only one of them, social responsibility and democracy, is found in the transformational literature. The two remaining concepts, listening ability/communication skills, and integrity, are not specifically found in the transformational leadership literature.

An alternative to changing the criteria of selecting the concepts to be used in the framework could have been substituted by other research methods. It might have been helpful to supply a subsequent questionnaire to panel members providing the final four nominated concepts and obtaining their feedback on these selections. Such information could have enhanced the research analysis by verifying results with the expert panel members. 
The researcher was satisfied with the analysis of the four selected concepts with the course outlines and syllabi presented in the Leadership Education Source Book (Clark \& Freeman, 1990). It was obvious that the information submitted by each school was limited and it would be difficult to verify that materials presented were actually being carried out in a leadership class or program. But the overview, purpose, or objective presented by each program indicated that most programs were aimed at teaching management and communication skills. This was also verified by the data presented by each program. Each of the nineteen programs could have been contacted individually to verify information, but this would have been difficult to logistically accomplish by the researcher.

Overall the researcher was satisfied with the qualitative research analysis carried out in this study. The research techniques developed around the Delphi Technique (Linstone \& Turoff, 1975) and the Focus Group Interview (Patton, 1990) provided a solid foundation for research inquiry. The triangulation methods strengthened the study through the use of several techniques in order to validate data used in the study.

\section{SUMMARY OF THE RESEARCH FINDINGS}

Qualitative research methods were used in this study to assemble a panel of experts who nominated a set of transformation leadership concepts to be used in an 
undergraduate student development leadership program. Seven expert panelists recommended an initial set of concepts. These results were compiled and panelists were given an opportunity to reevaluate their suggestions after reviewing the concepts suggested by all other panelists. Throughout the research process triangulation methods were included which enhanced the analysis. These procedures included comparing results to the current literature on transformational leadership and verifying whether or not the nominated concepts were contained in the course outlines and syllabi materials published in the Leadership Education Source Book (Clark \& Freeman, 1990) provided by The Center for Creative Leadership. Ultimately, four transformational leadership concepts were selected and these are presented in Figure 4.

Using the data compiled in this study a Eramework was established that specified transformational leadership concepts that could be integrated into an undergraduate student development leadership program. Such a model is important for leadership training as we move into the twenty-first century. With the social climate and culture of our world rapidly changing, theories that incorporate collaboration, tolerance, and an ethic of care and responsibility are essential components for all who endeavor to provide leadership strategies that will better enable all of us to meet the challenges of the future. 


\section{CHAPTER V}

\section{SUMMARY AND RECOMMENDATIONS}

\section{BACKGROUHD ISSUES}

Educating undergraduate students in the area of leadership has long been part of the educational mission of many public and private institutions of higher education in the United States. At many of these colleges and universities leadership education and training have been accomplished by programs directed by student development (also know as student affairs) divisions of the institutions. In a survey of over 1300 higher education institutions nationwide, Gregory and Britt (1987) reported that the student development profession administered over $25 \%$ of the programs. The 1990 edition of the Leadership Education Source Book (Clark \& Freeman) indicated that $30 \%$ of the leadership courses and programs were run by student development divisions. In commenting on the program findings cited by Gregory and Britt, Kenneth Clark (1986) stated that "For the most part, (the leadership programs) are management-development and training programs, rather than intel lectual explorations of leadership" (p. 19). Cheryl Mabey, Dean for student Development at Mount st. 
Mary's College in Los Angeles, had a similar view of leadership training at the college and university level when she stated that many "programs seldom have the objective of developing any functional leadership ability" (Callahan, 1985, p. 3).

The student development divisions of higher education institutions have a major role to play in leadership training. Historically, they have provided a variety of leadership programs that educated and trained students on the undergraduate level. But a close examination of these programs reveals that most of them provide nothing more than good management training. In this time of constant societal changes, there is a definite need for program models that embrace the complex problems facing our future leaders. Students that are only trained with communication and management skills, may not have the leadership expertise needed for the challenges that confront future leaders. Issues related to gender, diversity, and ethics are a few of the complexities that leaders must face. Future leaders must be enlightened with leadership education that embraces such arenas.

The notion of transformational leadership incorporates numerous ideas that may provide the fabric needed for a renewal of leadership training. First introduced by James MacGregor Burns (1978) in his book on leadership, transformational leadership offers a vision that builds on Burns' idea of raising individuals to higher levels of 
motivation and morality. Student development and student affairs undergraduate leadership programs could greatly enhance their leadership training by incorporating the views of transformational leadership. If this is accomplished, the student development profession will truly be meeting the challenges that face leadership training for the twentyfirst century.

\section{OBJECTIVES OF THE STODY}

The purpose of this study was to introduce a set of transformational leadership concepts that provided a Eramework for undergraduate college and university student development leadership programs. The primary purposes and objectives of this research were:

1. To identify what concepts experts say are necessary to introduce the topic of transformational leadership to undergraduate students in a student development leadership program.

2. To verify if each concept is present in the current transformational leadership literature.

3. To identify whether these transformational leadership concepts are included in the student development leadership course outlines or syllabi presented in the Leadership Education Source Book (Clark \& Freeman, 1990). 
4. To identify ways in which a transformational leadership concept could be integrated into a student development leadership program and specify what the actual framework of concepts would look like.

\section{METHODOLOGY}

The framework of transformational leadership concepts presented in this study was developed through suggestions submitted by a panel of experts. The methods used to formulate the questionnaires completed by the panelists were developed through the qualitative research methods which combined the Delphi Technique (Linstone \& Turoff) and the Focus Group Interview (Patton, 1990) method. These research techniques structured an anonymous group communication procedure which facilitated an emergent inquiry process. The design of the framework developed in this study relied on triangulation methods which used a combination of strategies to check findings against other sources and perspectives. Patton (1990) noted that such a process adds strength and validity to a study.

The criteria described in Chapter IV was used to select the expert panel members. Seven panelists were selected from a pool of thirty candidates. The transformational leadership concepts were nominated by the techniques specified in the questionnaires (see Appendices C\& I). Triangulation analysis procedures were used to choose the 
final four concepts which formulated the framework. A total of two questionnaires were used in the study and these were administered between June and october of 1992. The seven individual expert panel members completed and returned all the forms requested by the researcher.

\section{RESEARCH FINDINGS}

The questionnaires designed for this study structured a group communication process among the panel of experts. The panelists responded on paper returning their results to the researcher. This process allowed panel members the ability to freely express their own opinions and maintain their anonymity, avoiding possible biases that could occur with face to face committee meetings. These techniques allowed the research results to emerge and these findings answered the objectives and purposes of the study.

1. Expert panelists identified concepts necessary to introduce the topic of transformational leadership to undergraduate students in a student development leadership program.

2. The concepts were reviewed to verify if they were found in the transformational leadership literature.

This research revealed that four transformational leadership concepts nominated by the panelists met the criteria stated in Chapter IV for concepts to be selected 
for the framework. These four concepts were found in the transformations literature as outlined below.

Concept \# 1 EMPOWERMENT

Leadership as the practice of empowerment has strongly been advocated by feminist scholars such as Astin and Leland (1991). They viewed empowering leadership as collaboration, seeking the collective action of all those involved. Gilligan's (1982) and Miller's (1976) earlier works concur that problem resolution is at its best when it includes the relational aspects of problem solving. Hitt (1990) noted that James MacGregor Burns' idea of empowerment moved transformational leadership beyond transactional leadership. "Transformational leadership relies on empowerment as its principle means of motivation" rather than the transactional "carrot and stick approach of motivation" in terms of rewards and punishments (p. 164).

Concept \#2 VISION

Bennis (1989) called guiding vision, the "first basic ingredient of leadership" (p. 39). In an earlier work he defined vision as "the capacity to create and communicate a compelling vision of a desired state of affairs, a vision (or paradigm, context, frame - all those words serve) that clarifies the current situation and induces commitment to the future" (Bennis, 1984, p. 66). In a study of organizational leaders, Tichy and Devanna (1986b) found "transformational leaders were able to dream, able to translate those dreams and images so that other people could 
share them". They called these leaders, "visicnaries" ( $p$. 32). Foster (1988) saw vision as the means by which transformation occurred in leadership. "In kernel form it [transformation] simply says that a leader needs to have a vision for a better future, must communicate that vision in a manner that awakens others, and then must work towards its achievement" (p. 70). Fink's (1990) dissertation was a compeliing case study which concluded that vision was an essential component of transformational leadership. Concept \#3 VALUES/ETHICS

Burns (1978) said that transformational leadership was both moral and morally purposeful (p. 455). Foster (1989) stated that "leadership is founded on the fact of moral relationships; it is intended to elevate people to new levels of morality (p. 55). Forbes (1.991), Henrickson (1989), and Hitt (1991) united the meaning of values and ethics seeing those as crucial factors in the practice of transformational leadership. Tichy and Devanna (1986), and Karelis (1987) concurred that moral responsibility was at the heart of such leadership. Tierney (1991) could only view leadership as transformational by linking it to a moral component.

Concept \# 4 SHARED POWER/SHARED LEADERSHIP

Burns (1978) said that transformational leadership "occurs when one or more persons engage [emphasis original] with others in such a way that leaders and followers raise one another to higher levels of motivation and morality" ( $p$. 
20). Hosking and Morley (1988) showed leadership to be a relationship, the essence being that leadership is an interactive process between leaders and followers. Henrickson (1989) called for organizations to have shared understandings of the mutual purposes of both leaders and followers while Peters and Waterman (1982) spoke of influence being exerted by the transformational leader to obtain shared goals of both leader and follower. Rost (1991) added that such leadership should have an influence relationship between leaders and followers that reflects their mutual purposes. Blackmore (1989) presented a feminist reconstruction of transforming leadership which included a view of power which is multi-dimensional and multi-directional. In her monograph on the transformational leader, Forbes (199?) presented a partnership way of leading where power is seen as power with, rather than power over others.

3. How these transformational leadership concepts are included in the student development leadership course outlines or syllabi presented in the Leadership Education Source Book (Clark \& Freeman, 1990). The four transformational leadership concepts were examined with the college and university student development leadership courses and programs listed in The Leadership Education Source Book (Clark \& Freeman, 1990). A list of these nineteen programs is provided in Appendix L. 
Concept \# 1 EMPOWERMENT

Understanding the area of empowerment was specifically listed as a program objective by one college. In this program students developed their own leadership potentials understanding the concept of empowerment and how to empower others. No other school directly referred to empowerment in their program content.

Concept \#2 VISION

Two schools listed vision as the topic to be discussed at a scheduled class session. One of these schools listed the meaning of vision as a program objective to understanding leadership. Concept \# 3 VALUES/ETHICS

Some training in values and or ethics was commented on by ten of the schools. Much of the time this was found in the form of a strong statement included in the objective or overview of the school. Most all of these schools set aside a class session to cover topics pertaining to ethics and values. Some schools included an entire section of the program or course dedicated to this topic.

Concept \# 4 SHARED POWER/SHARED LEADERSHIP

Many schools listed texts in their reference or bibliography section which certainly include the ideas of shared power and shared leadership in some format. But it was more difficult to assess how many actually covered these topics in their sessions. For instance, several schoois covered gender issues as a topic, but it was not evident 
whether the feminist perspective of shared power or leadership was included. Even the notion of leaders as followers, which could be considered as shared power, was not found in the outlines. It was apparent that four of the institutions did include the concepts of shared power and shared leadership in their actual training programs.

4. Ways in which the transformational leadership concepts could be integrated into student development programs and what the actual framework of concepts would look like.

The panel members' expertise in instructional design for undergraduate students was made use of by acquiring suggestions from the panelists in three areas; (1) the sequence in which the transfcrmational leadership concepts should be taught to undergraduate students in a leadership program, (2) describing ways in which the transformational leadership concepts could be best communicated to undergraduate students, and (3) Iisting any books, articles, videos, or references of any kind which could be helpful in understanding leadership or helpful in implementing an undergraduate leadership program. These views recommended by the panelists, along with ideas found by the researcher in the literature, provide the framework of transformational leadership concepts which is presented here. The concepts are introduced in the sequence in which they were recommended (see Figure 5). 
Figure 5. Framework of Transformational Leadership Concepts [pp. 93-100]

\section{VALUES/ETHICS}

+ Values in the transformational literature is used in two ways, One way sees values as anything that improves the practice of individuals or enhances a particular setting. A second more common use of values in the literature links values directly with morals and ethics.

+ Most discussions on transformational leadership begin with a reference to Burns (1978) who first coined the term transforming leadership saying such leadership is both moral and morally purposeful.

+ The terms values, ethics, and morals are used throughout the transformational leadership literature. some authors make a distinction between the terms and some use them interchangeably.

\section{Delivery of Instruction on the concept}

* Provide opportunities for students to work on exercises where they can reflect on and list their own values and share those with others.

* Have students describe a work related ethical dilemma which they may have experienced.

* Engage students in a discussion of a case study where an ethical dilemma is presented.

* Promote values development through a service-learning component integrated into the leadership program.

* Introduce students to historical figures such as Martin Luther King Jr. and Mahatma Ghandi in terms of individuals who were transformational leaders and succeeded in shaping the values and goals of their followers. 
Resources for Commumicating the Concept

Avolio \& Bass (1988); Liethwood (1992); and Peters \& Waterman (1982) - All these authors join values with the improvement of a product or setting.
Burns (1978) - Resource for the original definition of transformational leadership that links the leadership process with raising individuals to higher levels of morality.

Delve, Mintz, \& Stewart (1990) - Journal article which provides a theoretical framework from which servicelearning programs can be developed.

Foster (1989, 1991) - Author calls for leadership to be both ethical and moral, using the terms synonymously.

"Ghandi," the movie \& "Eyes on the Prize," the PBS series. Use to discuss the life of Mahatma Ghandi and the life of Martin Luther King, Jr.

Grob (1984); and Barnett et al. (1992) - Authors state that morals and ethics are core values of leadership.

Hitt (1990) - Book is a valuable resource as a theoretical framework for ethics and leadership and putting this theory into practice. 


\section{Framework Content of the concept}

+ Having the capacity for vision is a basic ingredient of leadership.

+ Vision functions to inspire followers by giving their work meaning and facilitates the decision making process.

* Visionary leaders have the ability to communicate their visions.

+ Personality characteristics have been identified that are seen as visionary behavior on the part of leaders.

+ Visionary leaders are transformational in that they can dream and translate those dreams and images so that other people can share them.

\section{Delivery of Instruction on the concept}

\footnotetext{
* Involve students in the process of identifying their own personal vision or purpose. As a project, have them express this in some form by putting together a collage, or a series of lyrics from songs.

* Require that students identify and agree upon some type of communal vision where they would like to make a change in a club, organization, or the university environment. Save them identify the steps they would take to shape that vision. How would they use influence? How would they deal with the wants and needs of all those involved in the process?

* Focus the group on the future, 50-75 years from now. Have them share what that might be like. Then view and critique a video of someone else's view of the future (clip of a movie- i.e. "Jetsons"-the movie). Discuss that. Discuss how passion fits with a vision, the need to live it, and communicate it. Note that the basis of vision is values.

* Study a particular organization. Have students identify and discuss the symbols, myths, and traditions used to create and maintain the organization's vision. Fow is this vision communicated in the organization.
} 


\section{Resources for Communicating the Concept}

Bennis (1984, 1985, 1989) - The author provides great resources for discussing and interpreting vision.

Cosgrove, T. (1988)- Author discussed vision in leadership and gives an example of how setting vision goals leads to the most successful student government reign noted at The University of San Diego.

Cameron \& Ulrich (1986); Fink (1990); Foster (1988); and Tichy \& Devanna (1986) - All these authors link vision as an important characteristic of transformational leadership.

Peters \& Waterman (1982) - Good resource in how leaders inspire followers through vision and cultural actions.

Sashkin (1986) - Author links vision to charisma. Does a good job of identifying steps and behaviors that cultivate the making of a vision. The author did a study of Bennis and Nanus' (1985) work and identified five personality characteristics that could be seen as visionary behavior on the part of leaders. 
SHARED POWER AND SHARED

IEADERSEI I P

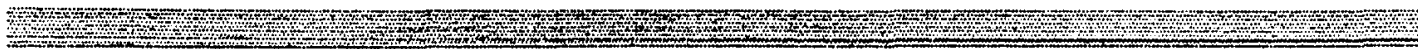

Framework content of the concept

* Transformational leadership is an interactive process between leaders and followers where the mutual purposes of all involved in the process are reflected.

$+\quad$ The shared goals of leaders and followers are represented in the leadership process.

$+\quad$ In the transforming leadership process power is multidimensional and multi-directional. In this process power is seen as power with, rather than power over others.

+ Shared leadership is a collective action where participants work together. In such an arena power is consensual and facilitative in nature.

Delivery of Instruction on the concept

* Engage students in activities that work with questionnaires and creative exercises that help them understand the leader/follower relationship of the transformational leadership process.

* Require that each student be responsible for obtaining the organizational chart of an organization. Have students bring these to class with enough copies for everyone in the class. Each student should be ready to discuss how shared power and shared leadership might work in the organization chart they brought to class. Have the class discuss these.

* Involve the students in a group class project to design an organization that will support the maximization of creativity for all involved in the company plus achieve some business purpose. Develop the organizational chart of such an organization. Then, analyze the organizational chart to focus on flexibility of leadership and followership functions.

* Encourage students as a group to explore the meaning of the common good. How could this meaning be incorporated into a particular community? How would leaders and followers interact in such a community? How would the ideas of shared power and shared leadership interface with this community? What could the community learn from the study of social theory viewed from Plato, Aristotle, Rousseau, Hobbes, Mills, and Dewey? 


\section{Resources for Communicating the Concept}

Educational Leadership, February 1992, Vol 49, No 2. This whole journal is dedicated to transforming leadership. A variety of articles are presented and include the concepts of shared power and shared leadership. Two expert panel members are contributing authors.

Foster (1991) - The author links transformative leadership with the concern for end values, where democratic communities are the goal and diverse voices may be heard. The sharing of power and leadership responsibilities are essential ingredients to achieve these results.

Hunt (1991) - Contains a variety of resources under the heading "Transformationally Orientated Training" (pp. 250-252).

Liberal Education, March/April 1987, Vol 73, No 2. This whole journal is dedicated to the study and practice of leadership. Several articles on the discourse and practice of leadership are included and these incorporate the concepts of shared power and shared leadership in the leader and follower relationship.

Rost (1991) - The author has provided a good resource for an up to date understanding of the leader/follower relationship which includes the views of shared power and shared leadership.

Starpower - This is a game in which a low-mobility, threetiered society is built through the distribution of wealth in the form of chips. This is an excellent resource for discussing issues of equity, fairness, power and control. Twenty five to thirty is the optimum number of participants.

The game is available from:

R. Garry Shirts

Western Behavioral Sciences Institute 1150 Silverado

La Jolla, California 92037 
$+\quad$ Empowering leadership is collaborative in practice and seeks the collective action of those involved in the process.

* Problem resolution is at its best when it includes the relational aspects of problem solving.

+ Empowerment moves transformational leadership beyond transactional leadership. Empowerment is used as the principle means of motivation in transformationl leadership rather than the rewards and punishments used to motivate in transactional leadership.

+ Particular themes have been identified in organizations when empowerment is present.

+ Although it is not gender specific, empowerment is more congruent with feminist values and the way women experience the world.

\section{Delivery of Instruction on the Concept}

* Stimulate curiosity on the part of students begin by using self assessment questionnaires and exercises to examine their own views and personal attitudes toward empowerment.

* Provide opportunities for students to study strategies, styles, and processes that empower others. Build on the ideas of shared power and shared leadership and develop these as aspects of empowerment.

* Introduce students to the works of Carol Gilligan and Lawrence Kohlberg in regards to decision making. Use examples to have them discuss how they would make decisions. Facilitate a discussion about how attitudes of care and responsibility affect people in empowering ways -

* Require that students participate in a class project where the person in charge consistently rotates to a different person each time. Role play some type of interaction where students are supposed to respond in gender role reversal. Discuss reactions and feelings of these events. This may best be accomplished in smali groups. 
Present a case study based on a policy-making process in an organization. Discuss the difference between power and influence in the roles people play in the organization. Have students identify situations where individuals empowered or were empowered by others in the policy-making process.

\section{Resources for Communicating the Concept}

Astin \& Leland (1991) - Chapter I of this book is a resource for strategies and processes that work to empower others.

Bennis (1989) - The author details four themes that are found in an organization when empowerment is present.

Forbes (1991) - This monograph presents a transformational leadership model which incorporates transformative values and principles based on the feminist perspective of empowerment.

Gilligan (1982); Kohlberg (1975); and Delve, Mintz and stewart (1990) - Kohlberg's work is based on decision making in regards to justice and rights which values a sense of separation for the individual. Gilligan provides a different view of decision making based on empathy and mutuality where attachment is seen as a value. Delve, Mintz and stewart combine both works to promote value development in the student development arena. Have students discuss how these different approaches relate to the empowerment theories. Relate empowerment to the concepts of values and ethics.

Hitt (1990) - The author makes the case that empowerment moves transformational leadership beyond transactional leadership.

Manz (1992) - The author provides a number of questionnaires, exercises, stories and case studies that can help students reflect on their own views of leadership and how the idea of empowerment can effect these views.

Ramey (1991) - The author presents the thesis that empowering leadership reflects a commitment to the quality of life, work, and society. 


\section{RESEARCHER RECOMMENDATIONS}

For the past three years the researcher has been exploring and investigating the area of transformational leadership in a leadership doctoral program at The University of San Diego. These studies have lead me to believe that there are some specific characteristics that contribute to the understanding of transformational leadership. The investigation design of this study focussed on obtaining recommendations of transformational leadership components from a diverse panel of experts. Some of the attributes significant to transformational leadership may have been omitted by the panelists in the final framework. Because of the possibility of omission, the researcher offers the following recommendations based on his concentrated studies done in the area of transformational leadership.

The researcher regards the component of change as an fundamental concept to be included in the leadership program. Transformational leadership is about change and creates change according to Foster (1991), Henrickson (1989), Tichy and Devanna (1986a, 1986b), and Tierney (1991). A good resource for understanding the concept of change is provided by Foster (1986a). His work provided an excellent analysis of why planned change in organizations fails. His critique of a variety of change models presented a clear insight into understanding the process of change. Senge's (1990) work was also useful in seeing the importance 
of interrelationships in an organization and subsequently seeing the patterns of change.

The researcher advocates that a concept of understanding one's world view be integrated into the leadership program. Although this idea is not found directly in the transformational leadership literature, understanding how we view our world certainly coincides with the ideas on vision, change, and empowerment found in the literature. The researcher suggests that acquainting students to the study of their own world views be introduced early on in the program. Helping students understand that their own slant or view of reality and the world is highly influenced by their particular culture, is a valuable insight on which to build the understanding of transformational leadership. There are many resources for comprehending the notion of a world view. Going back to Kuhn's (1970) work of two decades ago is a good start where he defined his understanding of a paradigm. senge (1990) provided a good understanding of world view in regards to understanding systems theory. Nicholas and Gobble (1991) wrote an article that is a great resource for a case study about health promotion analyzed from three different world views. A good video about paradigms is Joel Barker's "Paradigm Shift" video.

Finaliy, the researcher recommends that social responsibility be included as a concept of the transformational leadership program. Tierney (1991) 
believed that transformational leadership involved moral action that promoted social responsibility and subsequently democracy. It would fit that the concept of social responsibility should build from the study of morals, values, and ethics. But the researcher believes that social responsibility is so crucial to transformational leadership, that the concept should be emphasized alone. Some valuable works that unite social responsibility to transformational leadership include Burns (1978), Forbes (1991), Foster (1989, 1991), and Tierney (1991). Bellah et al. (1985, 1991) are excellent resources for understanding the importance of social responsibility.

\section{RECOMMENDATIONS FOR FURTHER RESEARCH}

The researcher was satisfied that the purposes and objectives of this study were met. If this study were to be replicated in the future, the researcher offers the following recommendations.

1. In order to alleviate misunderstandings over the semantic construction of responses by some of the panelists, it is recommended that a literature definition of each suggested concept be included with the feedback response. 2. It is recommended that an additional questionnaire be sent to the panelists in order to obtain individual feedback on the final set of concepts used in the framework. This information may have enhanced the research analysis by verifying the results with all of the panel members. 
3. The researcher believes that the set parameters used to select the concepts found in the framework were too stringent. The framework of the study may have been effected by these limited parameters.

The researcher offers the following recommendations for further studies to be done in the area of transformational leadership education in college and university student development leadership programs. 1. Pilot test a set of transformational leadership concepts by integrating them into an undergraduate student development leadership program.

2. Develop an extensive questionnaire study based on panelists' responses to a set of nominated transformational leadership concepts to be used in a leadership program. Such a study could provide valuable information for future leadership training.

3. Investigate a traditional teaching model of undergraduate student's concepts of transformational leadership. Study whether students have the intellectual capacity and personal maturity to comprehend seemingly ambiguous ideas about transformational leadership.

\section{CONCLUSION}

The student development profession has had a long history of producing innovative programs and training in the college and university setting. The profession has always prided itself in its concern for the development of the 
whole person and student development leadership programs have hoped to achieve this end. If the profession is truly going to make an impact in leadership training, the model must be sculptured from current studies in transformational leadership. It is the researcher's hope that the contributions from this study will provide the framework that can be used to take student development leadership education and training into the twenty-first century. 


\section{REFERENCES}

Adams, J. D. (Ed.). (1986). Transforming leadership: From vision to results. Alexandria, VA: Miles River Press.

Ambler, D. A. (1989). Designing and managing programs: The administrator role. In U. Delworth, G. R. Hanson, \& Associates (Eds.), student services: A handbook for the profession (pp 247-264). San Francisco: Jossey-Bass.

Anthony, P., \& Roberts, D. C. (1979). A comprehensive leadership program model. College Park, MD: (Mimeographed)

Astin, A. W. (1985). Achieving education excellence. San Francisco: Jossey-Bass.

Astin, H. S. \& Leland, C. (1991). Women of influence, women of vision: A cross-generationa $i$ study of leaders and social change. San Francisco: Jossey-Bass.

Avolio, B. J., \& Bass, B. M. (1988). Transformation leadership, charisma, and beyond. In J. G. Hunt, B. R. Baliga, H. P. Dachler, \& C. A. Schriesheim (Eds.), Emerging leadership vistas (PP. 29-50). Lexington, MA: Lexington.

Avolio, B. J., \& Gibbons, T. C. (1988). Developing transformational leaders; A life span approach. In $J$. A. Conger \& R. N. Ranungo (Eas.), Charismatic leadership (pp. 276-308). San Francisco: Jossey-Bass.

Avolio, B. J., Waldman, D. A., \& Einstein, W. O. (1988). Transformational leadership in a management game simulation. Group \& Organizational studies, 13, 59-80.

Barnett, B. G. Caffarella, R. S., Daresh, J. C., King, R. A., Nichoioson, T. H., \& Whitaker, K. S. (1992). A new slant on ieadership preparation. Educational Leadership, $49(5), 72-75$.

Bass, B. M. (1985). Leadership and performance beyond expectations. New York: Free Press.

Bass, B. M. (1990). Bass \& stodgill's handbook of leadershi (3rd ed.). New York: Free Press.

Bass, B. M., Waldman, D. A., Avolio, B. J., Bebb, M. (1987). Transformational leadership and the falling dominoes effect. Group \& Organization studies, 12, 73-87. 
Belenky, M. F., Clinchy, B. M., Goldberger, N. R., and Tarule, J.M. (1986). Women's ways of knowing: The development of self, voice, and mind. New York: Basic Books.

Bell, D. (1973). The coming of a post-industrial society: $A$ venture in social forecasting. New York: Basic Books.

Bellah, R. N., Madsen, R., Sullivan, W. M; Swidler, A., \& Tipton, S. M. (1985). Habits of the heart. Berkeley \& Los Angeles: University of California Press.

Bellah, R. N., Madsen, R., Sullivan, W. M., Swidler, A., \& Tipton, S. M. (1991). The good society. New York: knopf.

Bennis, W. (1984). Transformative power and leadership. In T. J. Sergiovanni \& J. E. Corbaliy (Eds.), Leadership and organizational culture (pp. 64-il). Urbana, IL: University of Illinois Press.

Bennis, W., \& Nanus, B. (1985). Leaders: The strategies for taking charge. New York: Wiley.

Bennis, $\mathrm{W}$ ( (1989). On becoming a leader. Reading, MA: Addison-Wesley.

Blackmore, J. (1989). Educational leadership: A feminist critique and reconstruction. In J. Smyth (Ed.), Critical perspectives on educational leadership (pp. 93-129). Philadelphia: Falmer.

Brandt, R. (1992). Overview: A different kind of leader. Educational Leadership, $49(5), 7$.

Brown, Patrick (1990). Student leadership program model. In M. B. Clark and F. H. Freeman (Eds.), Leadership education 1990: A source book. (PP. 226-231). Greensboro, NC: Center For Creative Leadership.

Burns, J. M. (1978). Leadership. New York: Simon \& Schuster.

Calder, B. J. (1977). An attribution theory of leadership. In B. M. Staw \& G. R. Salancik (Eds.)., New directions in organizational behavior (pp. 179-204). Chicago: st. Clair Press.

Callahan, M. M. (1985). Undergraduate leadership development. AAHE Bulletin, 35(7), 3-6.

Cameron, K. S. \& Ulrich, D. O. (1986). Transformational leadership in colleges and universities. In J. C. Smith (Ed.), Higher education: Vol. I. Handbook of theory and research (pp. 1-42). New York: Agathon. 
Chemers, M. M. (1984). The social, organizational, and cultural context of effective leadership. In $B$. Kellerman (Ed.), Leadership: Multidisciplinary perspectives (PP. 91-112). Englewood Cliffs, NJ: Prentice-Hall.

Clark, M. B., \& Freeman, F. H. (Eds.) (1990). Leadership education 1990: A source book. Greensboro, NC: Center For Creative Leadership.

Conger, J. A. (1989). The charismatic leader: Behind the mystique of exceptional leadership. San Francisco: Jossey-Bass.

Conger, J. A., \& Kanungo, R. N. (1987). Towards a behavioral theory of charismatic leadership in organizational settings. Academy of Management Review, 12, 637-647.

Conger, J. A., \& Ranungo, R. N. (1988). Charismatic leadership. San Francisco: Jossey-Bass.

Cosgrove, T. (1988). Cleaning up our language about leadership. Campus Activities Programing, 2I(3), pp. $40-45$.

Crookston, B. (1973). Education for human development. In C. Warnath and Associates (Eds.), New directions for college counselors: A handbook for redesigning professional roles. San Francisco: Jossey-Bass.

D'Antonio, M. (1992, March 22). Tough medicine for a sick America. Los Angeles Times Magazine, pp 32-50.

Delve, C. I., Mintz, S. D., \& Stewart, G. M. (Summer 1990) Promoting values development through community service: A design. New Directions for student Services, No. 50, pp. 7-29.

Denhardt, R. B. (1981). In the shadow of organization. Lawrence, KS: University Press of Kansas.

Denzin, N. K. (1978). The research act: $A$ theoretical introduction to sociological methods. New York: McGrawHill.

De Pree, M. (1989). Leadership is an art. New York: Doubleday.

Dill D. D., \& Fullagar, P. K., (1987). Leadership and administrative style. In $M$. W. Peterson, \& L. A. Mets (Eds.), Key resources on higher education governance, management, and leadership (pp. 390-411). San Francisco: Jossey-Bass. 
Fay, B. (1987). Critical social science. Ithaca, NY: Cornell University Press.

Fiedler, F. E. (1964). A contingency model of leadership effectiveness. In L. Berkowitz (Ed.), Advances in experimental social psychology (vol. 1). New York: Academic Press.

Fink, R. A. (1990). Vision: An essential component of transforming leadership. Unpublished doctoral dissertation. University of San Diego, San Diego.

Forbes, B. A. (1991). Profile of the leader of the future: origin, premises, values and characteristics of the Theory $F$ transformational leadership model. (Available from Dr. Beverly A. Forbes, P.O. Box 2131, Renton, WA 98056).

Foster, W. (1986a). Paradigms and promises: New approaches to educational administration. Buffalo: Promethers.

Foster, ผ. (1986b). The reconstruction of leadership. Victoria, Australia: Deakin University Press.

Foster, W. (1988). Leadership. Campus Activities Programming, 21(3), pp. 70-71.

Foster, W. (1989). Toward a critical practice of leadership. In J. Smyth (Ed.), Critical perspectives on educational leadership (pp. 39-62). Philadelphia: Falmer.

Foster, W. (1991). The administrator as a transformative intellectual. Peabody Journal of Education, 66(3), 518 .

Fried, H. J. (1989). Teaching and training. In U. Delworth, G. R. Hanson, \& Associates (Eds.), student Services: A handbook for the profession (pp 353-370). San Francisco: Jossey-Bass.

Gilligan, C. (1982). In a different voice. Cambridge, MA: Harvard University Press.

Gordon, Suzanne E., \& Sindon, Nancy A. (Fall 1989). Sources of additional information in the area of leadership development. NASPA Journal, 27(1), p. 85.

Graen, G., Alvers, K. M., Orris, J. B., \& Martella, J.A. (1970). Contingency model of leadership effectiveness: Antecedent and evidential results. Psychological Bulletin, 74, 285-296. 
Gregory, R. A. (1986). Leadership education in institutions of higher education: An assessment of practices. Unpublished manuscript

Gregory, R. A. \& Britt, S. K. (1987). What the good ones do: Characteristics of promising leadership development programs. Campus Activities Programmins, 20(2), 32-35.

Grob, L. (1984). Leadership: The socratic model. In B. Kell lerman (Ed.), Leadership: Multidisciplinary perspectives (pp. 263-280). Englewood Cliffs, NJ: Prentice-Hall.

Guba, E. G. \& Lincoln, Y. S. (1983). Epistemological and methodological bases of naturalistic inquiry. In $G$. F. Madaus, M. S. Scriven \& D. L. Stufflebeam (Eds.), Evaluation models: Viewpoints on educational and human services evaluation. Boston: Rluwer-Ni jhoff

Harman, W. W. (1976). An incomplete guide to the future. Stanford: CA: Stanford Alumni Association.

Harman, W. (1988). Global mind change. Indianapolis: Knowledge systems.

Hater, J. J. \& Bass, B. M. (1988). Supervisors' evaluations and subordinates' perceptions of transformational and transactional leadership. Journal of Applied Psychology. 73, 695-702.

Henrickson, R. L. (1989, March). Leadership, corporate behavior and the future. Paper presented at a symposium on Leadership: Exploring New Dimensions, San Diego, CA.

Hitt, ผ. D. (1990). Ethics and leadership: Putting theory into practice. Columbus, OH: Battelle Press.

Hollander, E. P., \& Julian, J.W. (1970). Studies in leader legitimacy, influence, and innovation. In L. Berkowitz (Ed.), Advances in experimental social psychology (vol. 5). New York: Academic Press.

Hosking, D. \& Morley, I. E. (1988). The skills of leadership. In J. G. Hunt et al (Eds.), Emerging leadership vistas (pp. 89-106). Lexington, MA: Lexington Books.

House, R. J. (1977). A 1976 theory of charismatic leadership. In J. G. Hunt \& L. L. Larson (Eds.), Leadership: The cutting edge (pp. 189-207). Carbondale: Southern Illinois University Press. 
Funt, J. G. (1991). Leadership: A new synthesis. Newbury Park, London: Sage.

Kahn, H., \& Bruce-Briggs, B. (1972). Things to come: Thinking about the 70 s and 80 s. New York: Macmillan.

Rarelis, C. F. (1987). The limits of leadership. Liberal Education, $73(2), 20-23$.

Kellerman, B. (Ed.). (1984). Leadership: Multidisciplinary perspectives. Englewood Cliffs, NJ: Prentice-Hall.

Kohlberg, L. (1975). The cognitive developmental approach to moral education. Phi Delta Kappan, No. 56, pp. 670-677.

Korman, A. (1966). Consideration, initiating structure, and organizational criteria-a review. Personal Psychology, $19,349-362$.

Kouzes, J. M., \& Posner, B. Z. (1987). The leadership challenge. San Francisco: Jossey-Bass.

Ruhn, T. S. (1970). The structure of scientific revolutions (2nd ed.). Chicago: University of Chicago Press.

Leithwood, R. A. (1992). The move toward transformational leadership. Educational Leadership, 49(5), 8-12.

Lincoln, Y. S., \& Suba E. G. (I985) Naturalisicic inguiry. Newbury Park: CA: Sage.

Linstone, H. A., \& Turoff, M. (Eds.). (1975). The delphi method: Techniques and applications. Reading, MA: Addison-Wesley.

Macintyre, A. (1981). After virtue, 2nd ed. Notre Dame, IN: University of Notre Dame Press.

Manz, C. C. (1992). Mastering self-leadership. Englewood Cliffs, NJ: Prentice Hall.

Miller, J. B. (1976). Toward a new psychology of women. Boston: Beacon Press.

Morril1, W. H., Hurston, J. C., \& Oetting, E. R. (1981). A conceptual model of intervention strategies. In $W$. $H$. Morrill \& Hurst (Eds.), Dimensions of intervention for student development ( $p$ p . 85-95). New York: Wiley.

National Association of Student Personnel Administrators (NASPA). (1987). A perspective on student affairs: A statement issues on the 50th Anniversary of the student personnel point of view. Washington, DC: Author. 
Nicholas, D. R. \& Gobble, D. C. (1991). World views, systems theory, and health promotion. American Journal of Health Promotion, $6(1), 30-34$.

Noddings, N. (1984). Caring: A feminine approach to ethics and moral education. Berkeley, CA: University of California Press.

Palmer, R. E. (1989, January). Forgei managers; what we need are leaders. Business Month, 10, pp. 69-70.

Patton, M. Q. (1990). Qualitative evaluation and research methods. Newbury Park, CA: Sage.

Perry, W., Jr. (1970). Intellectual and ethical development in the college years. New York: Holt, Rinehart, and Winston.

Peters, T., \& Waterman, R. (1982). In search of excellence. New York: Harper \& Row.

Roberts, Dennis C. (1981). Student leadership programs in higher education. Carbondale, IL: Southern IIlinois University Press/American College Personnel Association.

Roberts, N. (1985). Transforming leadership: A Process of collective action. Human Relations, 38(II), 1023-1046.

Rost, J. C. (October, 1985). Distinguishing leadership in the postindusirial era (Revised edition). San Diego: University of San Diego, School of Education.

Rost, J. C. (February, 1989). The nature of leadership in the postindustrial era (Revised edition). San Diego: University of San Diego, School of Education.

Rost, J. C. (1991). Leadership for the twenty-first century. New York: Praeger.

Saddlemire, G. L. (1988). Student activities. In A. I. Rentz \& G. L. Saddlemire (Eds.), student affairs functions in higher education (pp. 261-283). Springfield, IL: Charles C. Thomas.

Sashkin, M. (1986). True vision in leadership. Training and Development Journal, $40(5), 58-61$.

Schuh, J. H. (1988). Residence Halls. In A. L. Rentz \& G. L. Saddlemire (Eds.), student affairs functions in higher education (PP. 227-260). Springfield, IL: Charles C. Thomas. 
Senge, P. M. (1990). The fifth discipline: The art and practice of the learning organization. New York: Doubleday/Currency.

Sergiovanni, T. J. (1990). Value-added leadership: How to get extraordinary performance in schools. San Diego: Harcourt, Brace, Jovanovich.

Stogdill, R. M. (1948). Personal factors associated with leadership: A survey of the literature. Journal of Psychology, 25, 35-71.

Smyth, J. (Ed.). (1989). Critical perspectives on educational leadership. London, oR: Falmer.

Tichy, N. M., \& Devanna, M. A. (1986a). The transformational leader. New York: Wiley \& Sons.

Tichy, N. M., \& Devanna, M. A. (1985b). The transformational leader. Training and Development Journal, 40(7), 27-32.

Tierney, W. G. (1991). Advancing democracy: A critical interpretation of leadership. Peabody Journal of Education, 66(3), 157-173.

Watkins, B. T. (1986). Critics say colleges do a poor job of developing leadership qualities in their undergraduates. The Chronicle of Higher Education, I921 .

Wood, N. L., Wood, R. A., \& McDonald, T. D. (1988) Integration of student development theory into the academic classroom. Adolescence, 23(9), 340-358.

Yukl, G. A. (1989). Leadership in organizations (2nd ed.) Englewood Cliffs, NJ: Prentice-Hall.

Zaleznik, A. (1977). Managers and leaders: Are they different? Harvard Business Review, 55(3), pp. 67-68.

Zaleznik, A. (1989). The managerial mystique: Restoring leadership in business. New York: Harper \& Row. 


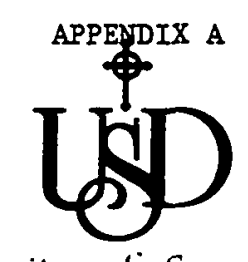

University of San Diego

School of Education

June 15, 1992

\author{
Name \\ Title \\ University \\ Address \\ City, State, Zip
}

\title{
Dear (Name)
}

I am a student in the doctoral leadership program at the University of San Diego. As my dissertation project, I have chosen to develop a transformational leadership model that could be integrated into undergraduate college and university student affairs/ development leadership programs.

Your name was suggested to me as an individual who has expertise in the area of transformational leadership. You are invited to participate in this study by suggesting what transformational leadership concepts are necessary to introduce and to integrate the topic of transformational leadership to traditional undergraduates (i.e. , 18-21 y/o) in a student affairs/development leadership program. The model developed in this study could make a significant contribution since many leadership programs focus only on skills building and management techniques. This study will attempt to suggest the need for such a model, and make practical suggestions showing how transformational leadership concepts can be integrated into existing student affairs/development leadership programs.

Please fill out the enclosed questionnaires which will provide me with your background information and further data for establishing a model for transformational leadership programs. After all the responses are received, an expert panel will be formed that meets the criterion established for my dissertation. You will receive a letter from me in August informing you whether or not you have been selected as a panel member. 
If you are selected and have agreed to participate in this study, you will receive in the mail a list of other panelist responses regarding what they suggested would be necessary to introduce the concepts of transformational leadership to undergraduate students. In this second follow up questionnaire you may make further recommendations in light of this information. You will also be asked to rank your final recommendations in the order of priority that you think they should be taught and suggest ways in which these concepts could be best communicated to traditional undergraduate students. The questionnaire will arrive in September and should take you no more than one half hour to complete. At no time during the panelist process will your name be revealed to other panel members.

Thank you for your consideration in being a part of this study. If you have any questions, please do not hestitate to call me collect at home, (619) 688-0835. Your prompt return of the questionnaire and consent form in the stamped selfaddressed envelope will be greatly appreciated.

Sincerely,

\section{Stan Fasci}

Note: If you do not wish to participate as a panel member, please check here and return this page in the envelope provided.

I do not wish to participate in this study.

Name 


\section{BACKGROUND INFORMATION QUESTIONNAIRE}

What forms your knowledge base of transformational leadership?

(i.e. , educational training, workshops, seminars, held position or taught in leadership program, professional writing/ reading).

What is your knowledge of college and university student affairs/ development leadership programs?

- In what capacity have you worked with traditional undergraduate college students ? (i.e., 18-21 y/o) 
TRANSFORMATIONAL LEADERSHIP CONCEPTS QUESTIONNAIRE

What transformational leadership concepts do you say are necessary to introduce and integrate the topic of transformational leadership to traditional undergraduates ( i.e., 18-21 $\mathrm{y} / \mathrm{o}$ ) in a student affairs / development leadership program ?

Please list five.

1.

2.

3.

4.

5.

Feel free to add additional concepts. 


\section{UNIVERSITY OF SAN DIEGO CONSENT TO ACT AS AN EXPERT PANEL MEMBER}

Note: This consent form is a requirement of the University of San Diego's Human Subjects Committee for faculty and dissertation research studies.

Stan Fasci, a doctoral student at the University of San Diego, is developing an undergraduate student development leadership model to be used in college and university leadership programs. If I am selected as an expert panelist, I understand that I will be making recommendations on a questionnaire to suggest transformational leadership concepts to be used in the model.

I understand that the participation in this study should involve few risks or little discomfort to me since my participation in the study is voluntary. I understand that I have the option of designating that my name remain confidential as a panelist member or that i may give the researcher the permission to publish my name, title, and responses in the completed dissertation. I will check one of the boxes below designating which I prefer. In either case, I understand that I may refuse to participate or may withdraw from the panel at any time during my participation. I further understand that there is no agreement, written or verbal, beyond that which is expressed in this consent form.

Stan Fasci has explained this study to me in a cover letter and has supplied me his home phone number, (619) 688-0835, which I may call collect, should I have any questions or encounter any difficulties as a panelist.

I, the undersigned, understand the above explanations and give my consent to voluntary participation in this study. I have checked below whether or not I want my name to remain confidential as a panel member.

I, the undersigned, want my name to remain confidential as a panel member and do not want to be identified in any way as a participant in the study.

\section{OR}

I, the undersigned, give permission to Stan Fasci to publish my name, title, and responses in his completed dissertation study. I would like my name and title to be stated as I have printed here:

Name

Title

Complete grey box on page 2. 
Consent Form, page 2.

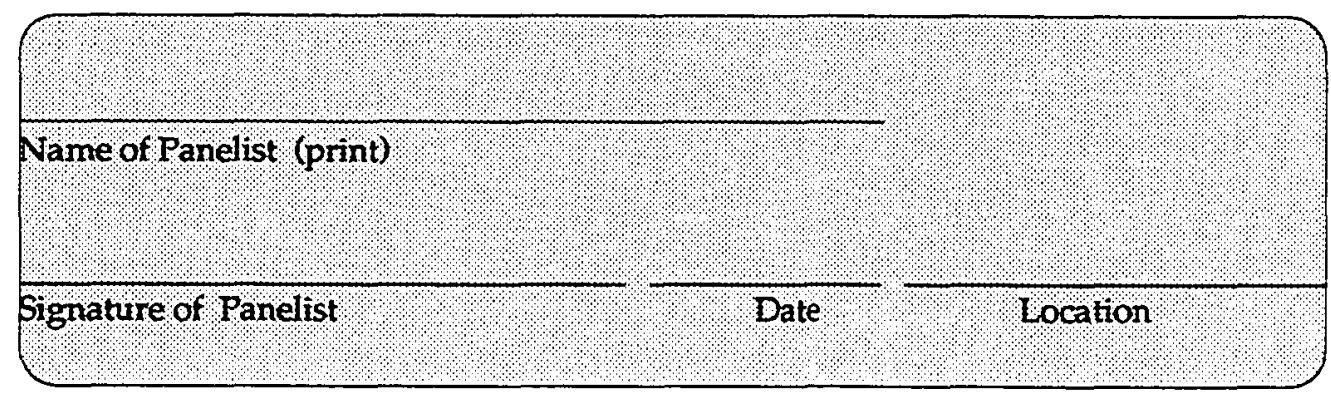

Done at

City

State

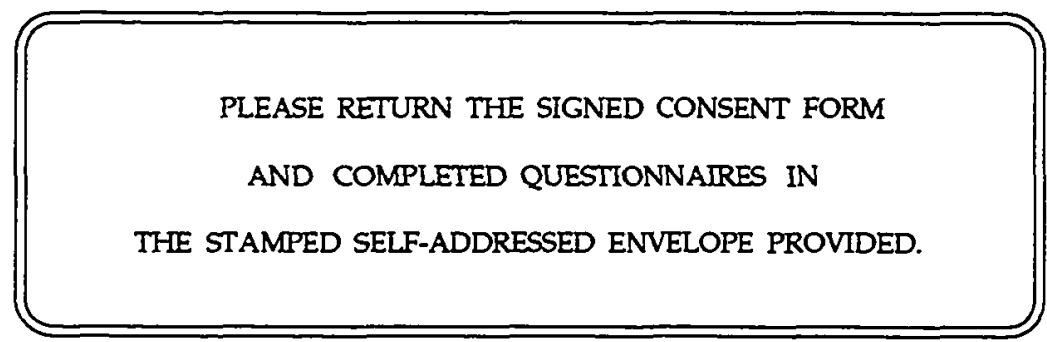

Reproduced with permission of the copyright owner. Further reproduction prohibited without permission. 


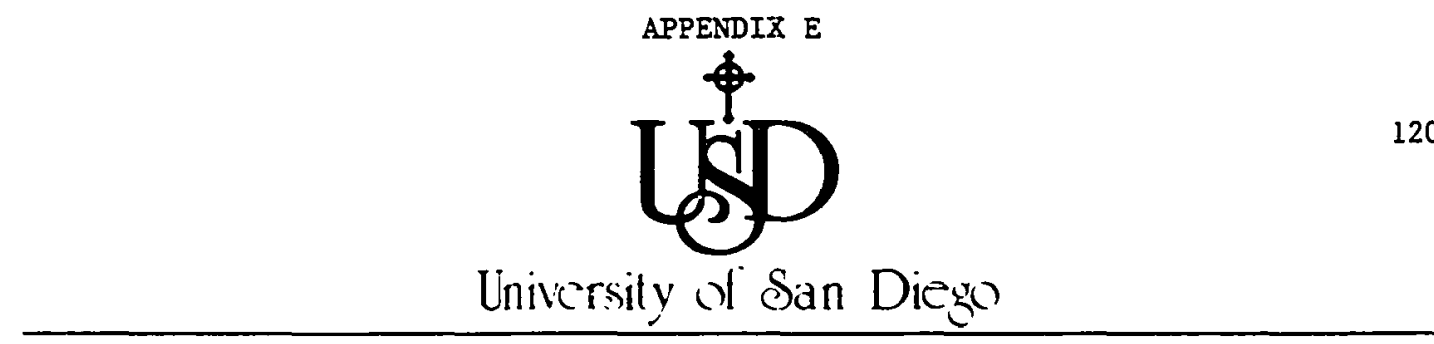

School of Education

August 25, 1992

\author{
Name \\ Title \\ University \\ Address \\ City, State, Zip
}

\title{
Dear (Name),
}

Thank you for the response to my request to suggest concepts to be used in an undergraduate transformational leadership program. Your suggestions are valued and appreciated.

Unfortunately, due to the criteria established in my dissertation proposal, I will not be able to use you for the second round of responses.

Thanks again, and I wish you success in your own work.

Sincerely,

Stan Fasci 


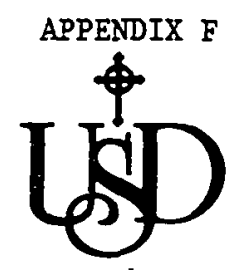

University of San Diego

School of Education

August 25, 1992

\author{
Name \\ Title \\ University \\ Address \\ City, State, Zip \\ Dear (Name),
}

Thank you for your response to my request to be a panel member in my dissertation project. I am pleased to inform you that you have met the criteria established in my dissertation proposal. Along with six others, you have been selected as an expert panel member.

Within the next few weeks you will be receiving a packet in the mail which will contain the responses of the other six panel members. You will be asked to evaluate those responses and you will be given the opportunity to make further suggestions. The whole process should take no longer than thirty minutes of your time.

Thanks again and you can expect the final packet in the mail by mid September.

Sincerely,

Stan Fasci 
Name

Title

University

Address

City, State, Zip

Dear (Name),

Thank you again for your response to be a panel member in my dissertation project. Enclosed you will find your responses along with the six other individuals who were selected as expert panel members.

In the enclosed packet you are asked to evaluate the responses of panel members and make any additional recommendations

of your own. The assessment is divided into four parts. Begin with Part $I$ and follow the directions as indicated. The whole assessment process should take no longer than thirty minutes of your time.

As one of only seven expert panel members, your response is very valuable to this dissertation project. Know that I appreciate the expertise you offer. Please drop the packet in the mail by October 1 , 1992. A stamped, self-addressed envelope is enclosed for your convenience.

Sincerely,

Stan Fasci

(619) 688-0835 


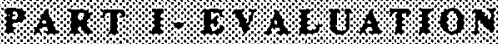

The following are a list of the seven panel members responses to the question:

What transformatinsal leadership concepts do you say are necessary to introduce the topic of transformaltional leadership to tradutional undergraduales (i.e., 18-21 y/o) in a student affairs/development leadership program?

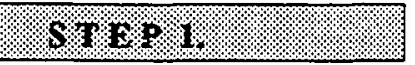

For each statement below, circle the letter which most reflects your position on whether or not the concept should be included in the leadership program.

a..........Agree that it should be included

b.........Not certain, but willing to consider including this.

c........ Disagree that this should be included.

\section{S. \% F P 2 .}

For each statement where you mark"c", indicate in the space below statement, or on back of page, why you do not think the concept fits or how you would like it amended. [Your own set of concepts is indicated with an asterisk]

\section{PANEL MEMBER \# I}

1. Listening ability.

2. Personal vision development.

3. Presentation of self.

4. Collegial reliance.

5. Communication skills. a $\quad$ b $\quad$ c

a $\quad$ b $\quad$ c

a b $\quad$ c

a b c

a b c 
2.

PANEL MEMBER \# II

1 Not related to positions in an organization, but is relational. Flip flopping a b c of who is a"leader" and who is a"follower" over time according to contexts.

2. Ethical component. Both the ethics of a free relationship based on mutual a b c purposes as well as exploration of the concepts of the common good.

3. The expanded concept of followership---followers empower leaders.

a b c

4. Vision and visioning..-What it is, how it's developed, how communicated?

a b c

5. How is change created in organizations----importance of time, historical fit, vision.?

\section{PANEL MEMBER \# III}

1. Service .

a $\quad$ b c

2. Integrity .

a b c

3. Faith in humanity.

a b c

4. Hope.

a b c

5. Empowerment.

a b c

\section{PANEL MEMBER \# IV}

1. Function of a vision: Sharing with others.

a b $\quad$ c

2. Human engineering skills: Involving others in the vision.

a $\quad$ b c

3. Commitment to the vision: Do whatever it takes.

a b c

4. Developing structures \& communication systems.

a b c

5. Empowering :thers to tackle challenges.

a b c 
1. Human values.

2. Motivation.

3. Social responsibility.

4. Institution building.

5. The nature of heroism.

PANEL MEMBER \# VI

1. Issues of ethics and morality.

2. Issues of social justice / democracy.

3. Vision / hope.

4. Empowerment--- What does it mean?

5. Leaders as followers.

PANEL MEMBER \# VI

1. Empowerment

2. Trust

3. Values

4. Development

5. Influence a b c

a b c

a b c

a b c

a b c

a b c

a b c

a b c

a b c

a b c

a b c

a b c

a b c

a b c

a b c 


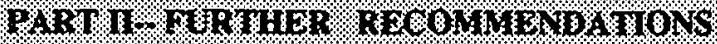

4.

The following are a list of your recommendations to the question:

What transformational leadership concepts do you say are necessary to intraduce the topic of transformational leadership to traditional undergnaduates (i.e., 18-21 y/o) in a student affairs/development leadership program.

Please do the following on this page.

\section{STEP: $1 \%$}

Now that you have seen the responses of the other six panel members, you may want to change your recommendations or add additional ones.

If you wish to delete a recommendation, just cross a line through the recommendation. You may add a recommendation by writing it below the one you crossed out.

- If you want to keep all five of your original recommendations plus add additional ones, use the spaces \# 6 and \# 7 to add additional ones. Use the back of the page if needed.

- If you want to make no changes in your original recommendations, leave page as is.

\section{PANEL MEMBER \# VII}

1. Empowerment.

2. Trust.

3. Values.

4. Development.

5. Influence.

6.

7.

\section{$\mathrm{STEP}=2$}

In the boxes above, suggest the sequence in which these concepts should be taught to traditional undergraduate students in a leadership program. 


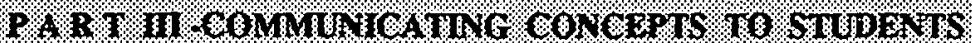

5.

\section{ST:191.}

If you made any changes to your recommendations or added any additional ones on the previous page, make the same changes here on this page.

\subsection{2}

Now, under each concept, please suggest ways in which this concept is best communicated to undergraduate students. Be as creative as you like!

PANEL MEMBER \# VII

1. Empowerment.

2. Trust.

3. Values.

4. Development.

5. Influence.

6.

7.

Reproduced with permission of the copyright owner. Further reproduction prohibited without permission. 
6.

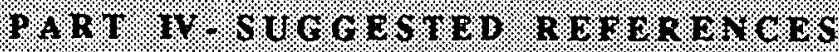

Please list below any books, journals, articles, videos, or references of any kind which you feel may be helpful to the understanding of leadership or helpful in implementing an undergraduate leadership program. 
A list of the nineteen college and university student development leadership courses and programs found in the Leadership Education Source Book (Clark \& Freeman, 1990).

* Ball State University, Muncie, IN

* Creighton University, Omaha, NE

* Cypress College, Cypress CA

Mount St. Mary's College, Los Angeles, CA

* Nebraska Wesleyan University, Lincoln, NE

North Carolina State University, Raleigh, NC

St. Norbert College DePere, WI

St. Olaf College, Northfield, MN

* Southeast Missouri State University, Cape Girardeau, MO

The University of Vermont, Burlington, VT

University of California, Davis, CA

University of Hawaii, Hilo, HI

University of Minnesota, Minneapolis, MN

* University of Nebraska, Lincoln, NE

University of New Hampshire, Durham, NJ

University of North Carolina, Chapel Hill, NC

University of San Diego, San Diego, CA

University of South Carolina, Columbia, SC

University of Wisconsin, Stevens Point, WI

* Denotes that information was listed as a course 